\title{
Mapping out the path ahead for corporate criminal procedure law in People's Republic of China
}

\author{
Traçando o caminho do futuro para o Direito processual \\ penal da pessoa colectiva na República Popular da China
}

Hugo Luz dos Santos ${ }^{1}$

\begin{abstract}
Faculty of Law of University of Macau, People's Republic of China Forum for International Conciliation and Arbitration (Oxford, United Kingdom)

hugo.miguel.luz@gmail.com

https://orcid.org/0000-0003-0297-3546
\end{abstract}

\begin{abstract}
The tale of procedural fairness is, by now, familiar and well worn. People's Republic of China criminal system of justice, which is currently gearing towards the pathway of procedural fairness, has (for the better or for the worse) attracted a wide global gaze. Irrespective of the underlying fairness (or the lack thereof) of the grievances brought forth by a worldwide phalanx of critics, China is steadily toiling towards the path of procedural justice, which is rooted firmly in the Rule of Law. Whilst procedural justice and procedural fairness map seamlessly on to the context of corporate criminal procedure law, there is bevy of critical questions that are in dire need of being consistently addressed nonetheless. One which is whether and to what extent politicallycharged tools, which seemingly belie the western-borne concept of separation of powers (as the Supreme People's Procuratorate Guiding Cases and, to some degree, Supreme People's Court Judicial Interpretations) are amenable to forge the path ahead to meeting the fundamental tenets of due process in corporate criminal procedure law in Mainland China. Against this background, this paper aims to answer
\end{abstract}

1 Bachelor Degree in Law (Faculty of Law of Coimbra, Portugal). PhD in Law (2019-2021), Faculty of Law of the University of Macau, China). Part-Time Lecturer at Faculty of Law of University of Macau (People's Republic of China). Fellow at Forum for International Conciliation and Arbitration (FICA, Oxford, United Kingdom). Awarded with the Fellowship of the Royal Society of Arts of United Kingdom (London, United Kingdom) "for outstanding contributions to rule of law, justice and policy worldwide". 
two sweeping research questions. Firstly, the degree to which corporate governance (and corporate compliance) subdues (and foremost trumps) corporate criminal liability. Secondly, whether and to what extent SPP Guiding Cases have catalyzed a seismic shift in People's Republic of China criminal procedural law. Conversely, one central contention of this paper is that a set of fairness-fraught corollaries can be withdrawn from SPP Guiding Cases with a view to map the path forward to fulfilling the baseline standards of both procedural fairness and procedural justice in People's Republic of China corporate criminal procedure law.

KeYwords: Corporate criminal procedure law; People's Republic of China; Supreme People's Procuratorate Guiding Cases; procedural fairness; procedural justice; due process.

Resumo: A narrativa que gravita em torno da justiça processual é, no momento que nos interpela, assaz conhecida. O sistema de administração de justiça penal chinês, que está a encetar uma consistente trajectória de aproximação aos prolegómenos essenciais da justeza processual, tem (para o bem ou para o mal) granjeado atenção à escala global. Sem embargo da justeza (ou falta dela) do entono crítico desferido por uma plêiade de detractores à escala mundial, a China tem envidado hercúleos esforços no sentido de caminhar na direcção da justeza processual, que se propugna firmemente no Estado de Direito. Embora a justeza processual e a justiça processual se enquadrem harmoniosamente no desenho funcional do processo penal da pessoa colectiva, denota-se, contudo, a existência de um conjunto de questões nucleares que devem ser consistente e acuradamente abordadas. De entre as quais se enumera a questão de se saber em que medida instrumentos de cariz vincadamente político, que, aparentemente, brigam frontalmente com conceitos jurídicos anquilosados no ideário jurídico ocidental, como o princípio da separação de poderes (v.g. os Casos Vinculantes emitidos pela Procuradoria Geral do Povo Chinês ou, de forma essencialmente similar, as interpretações judiciais gizadas pelo Supremo Tribunal do Povo Chinês) avocam a virtualidade de encetar, em si mesmo tomados, uma trajectória (consistente) de aproximação aos pilares identitários de um processo justo e equitativo, que se move no horizonte funcional do processo penal da pessoa colectiva da China Continental. Ancorados no enquadramento temático que antecede, este artigo doutrinal tem como objectivo primacial responder a duas questões-volantes. Em primeiro lugar, em que medida o governo societário (e o cumprimento normativo) fagocita (e, sobretudo, pulveriza) a responsabilidade penal da pessoa colectiva. Em segundo lugar, se e em que medida de significado funcional os Casos Vin- 
culantes esculpidos laboriosamente pela Procuradoria Geral do Povo Chinês tiveram o condão de provocar uma mudança de paradigma no processo penal da República Popular da China. De tal facto se infere que uma das ideias motrizes que avulta deste artigo doutrinal radica no axioma de que se pode decantar (ou extrair) um conjunto de corolários jurídicos (que são vastamente perpassados por considerações de justeza processual) dos Casos Vinculantes emitidos pela Procuradoria Geral do Povo Chinês, que se colimam à criação de parâmetros referenciais de justeza processual e de justiça processual em torno dos quais deverá gravitar o processo penal da pessoa colectiva da República Popular da China.

Palavras-chave: Direito processual penal da pessoa colectiva; República Popular da China; Compilação de Casos Vinculantes emitidos pela Procuradoria Geral do Povo Chinês; justeza processual; justiça processual; processo justo e equitativo.

摘要：

迄今为止，程序上公平的故事已经为人熟知且司空见惯 了。中华人民共和国的刑事司法系统正在走向程序公正化的道 路, 它已经 (无论好坏) 都吸引了全球的关注。不管世界各地 的批评者提出的不满是否公平, 中国都在稳步地朝着扎根于法 治的程序正义道路努力。虽然程序正义和程序公平无缝地映射 到公司刑事诉讼的背景下，但仍有一些关键问题迫切需要得到 解决。这个制度是否以及在多大程度上带有政治色彩，该制度 似乎与西方的三权分立概念背道而驰（如最高人民检察院指导 性案例，最高人民法院的司法解释等在某种程度上的体现）。 但这个制度能够开拓前进的道路，以符合中国内地公司刑事诉 讼中正当程序的基本原则。

在此背景下，本文旨在全面回答两个的论题：首先，公 司治理（和公司合规）在多大程度上降低了(最重要的是胜 过）公司刑事责任。其次，最高人民法院指导性案例是否以 及在多大程度上促进了中华人民共和国刑事诉讼法的巨变。

反之，本文的一个中心论点是，可以从最高人民法院指 导性案例中取出一系列充满公平性的推论，以绘制出实现中华 人民共和国程序公平和程序正义基线标准的前进道路一一中国 公司刑事诉讼制度。 
SUMmary: Introduction; 1 The design of effective corporate compliance programs matters indeed: The interplay between corporate governance and the minimization of corporate criminal liability; 2.The procedural legality turn in the criminal procedure law of People's Republic of China catalyzed by Supreme People's Procuratorate Guiding Cases: Introduction; 3.Fairness-fraught corollaries than can be withdrawn from the legality turn catalyzed by SPP Guiding Cases: The right to a fair trial and the right to an effective defence should be allotted to corporations; 4 . Concluding remarks; References.

\section{INTRODUCTION}

People's Republic of China's criminal procedure law stands at a critical juncture: clutch both social stability and legal security amidst troubled times. Yet troubled times, albeit conflict-ridden, seldom stand in the way of change. Rather, troubled times, if nothing else, unlock endless opportunities to gain access to the hallowed stairways of legality. Troubled times, like rocky roads, often lead to dazzling (even riveting) destinations. No matter how quixotic and paradoxical that may sound at first blush.

Axiomatic as it is, China has weathered the storm of legal havoc which has beset (and therefore frayed) the fabric of its criminal procedure law for a long-drawn-out ${ }^{2}$. The pendulum of procedural fairness has thereby swung far and hard against the abhorrent unlawfulness, which rendered legal havoc tokenistic.

The quintessential Supreme People's Procuratorate (SPP) Guiding Cases played a pivotal role in catalyzing a seismic shift (towards procedural

2 Hawes, Colin, Transforming the culture of Chinese Prosecutors through Guiding Cases, New Criminal Law Review, 23, n. ${ }^{\circ}$ 2, 2020, pp. 196-235 (posits that "during regular "strike hard" campaigns against crime from the 1980's to early 2000s, this has led them to prosecute suspects indiscriminately (in collaboration with police and courts), without regard to proportionate sentencing principles, in order to meet arbitrarily quotas for criminal conviction"). Concurring: Shiyuan, Huang, Chinese Wrongful Convictions: Causes and Prevention, University of Cincinnati Law Review, 80, 2012, pp. 1218 and ff. 
fairness) in People's Republic of China criminal procedural law while vanquishing (and in the overwhelming majority of the cases lashing out and upending) the greatest foes of due process of all: raging legal havoc and gruesome injustice. As a result, perceptions of procedural fairness, a by-product of both due process and natural justice ${ }^{3}$, are currently the norm rather than the exception in People's Republic of China criminal procedural law.

Perceptions of procedural fairness, which are paramount to instill trust upon defendants ${ }^{4}$, are slowly (yet steadily) being doled out to the latter in a regular basis. Which embodies nothing but a yearning hope that things (procedurally speaking) are to bode well in China as perceptions of procedural fairness (coupled with a sought-after procedural justice) amount as the harbinger (truly the forebear) of legal security and due process, which, taken together, are not by any means to be shrugged off in the remit of criminal procedural law ${ }^{5}$.

3 The principle of natural justice is deeply woven into the fabric of natural law, whose pillars were laid down by Hugo Grotius and Leibniz and subsequently embraced by John Finnis. See, respectively, Grotius, Hugo, Le droit de la guerre et de la paix, II, cap. XVII, I. Paris: Presses Universitáires de France ( $2^{\text {nd }}$ edition of 2016) (1625: 1st edition), pp. 1-894 (this learned author contends that the human community (and law) is (are) underpinned by the human reason as opposed to the serpentine, fiddly and whimsical instinct. Such a stance dovetails smoothly with a Latin maxim, which reads as follows: Ius naturale est dictatum rectae rationis). In Latin language: Leibniz, Gottfried Wilhelm, Nova methodus discendae docendaeque jurisprudentiae (The New Method of Learning and Teaching Jurisprudence According to the Principles of the Didactic Art Premised on the General Part and in the Light of Experience: A Translation of the 1667 Frankfurt Edition with Notes by Carmelo Massimo de Iuliis. Ringwood, Hampshire, United Kingdom: Talbot Publishing, 2017, pp. 1-213. Finnis, John, Natural Law and Natural Rights, $2^{\text {nd }}$ edition. Oxford: Oxford University Press, 2011/2018, pp. 1 ff and passim (contends that is crucially important to ferret out the set of reasons that favour having law - or a universe of regulations consistent with the rationale behind the former - from the "first-person perspective of practical reason").

4 Hussemann, Jeanette/Siegel, Jonah, Pleading Guilty: Indigent Defendant Perceptions of the Plea Process, Tennessee Journal of Law and Policy, 13, 2019 (highlighting the multifarious benefits of procedural fairness and procedural justice in criminal procedure law from the perspective of the defendant).

5 Johnson, Thea, Public Perceptions of Plea Bargaining, American Journal of Criminal Law, 46, n. ${ }^{\circ}$ 1, 2019, pp. 133-156 (136) (argues that criminal 
Law and order, one of the flagships of modern China, seeks both to fight crime ${ }^{6}$ and attain social control. In an earnest attempt to grasp such a laudable goal, both fairness and transparency ${ }^{7}$ (as opposed to an illegal and thereby harrowing disfranchisement of civil rights ${ }^{8}$ ) must be at the forefront of clean and seamless criminal proceedings. Lest a given system of administration of justice wants to shun the jarring sobriquet of "mockery of justice", fairness and transparency must spearhead criminal proceedings. Unlawfulness, the twin brother of legal havoc, must be trounced if a given system of criminal justice is to climb up the ladder that leads to the Olympus of procedural legality: due process, which dwells on the other end of the spectrum of both procedural fairness and procedural justice. Be that in China or elsewhere. It is no different in the remit of corporate criminal procedure law ${ }^{10}$.

To the extent that fairness and transparency play (in concert) a key role in shaping a seamless corporate criminal procedure law in People's Republic of China, corporations must be allotted clear and unambiguous

procedure law is of paramount importance "as the criminal justice touches the lives of so many people in the country").

6 Bandes, Susan A., Video, Popular Culture, and Police Excessive Force: The Elusive Narrative of Over-Policing, University of Chicago Legal Forum, 2018, pp. 1-3 (states that "policing as an exercise in crime-fighting and peace-keeping").

7 Bibas, Stephanos, Transparency and Participation in Criminal Procedure, New York University Law Review, 81, 2006, pp. 911 ff.

8 Bains, Chiraag, "A Few Bad Apples": How the Narrative of Isolated Misconduct Distorts Civil Rights Doctrine, Indiana Law Journal, 93, 2018, pp. 29 and ff (argues that police misconduct undermines, taints and sullies constitutional protections afforded to defendants in criminal procedure law).

9 Byrne, Mari, "Baseless Pleas: A Mockery of Justice”, Fordham Law Review, 78, 2010, pp. 2961 and ff.

10 Reilly, Peter, Negotiating Bribery: Toward Increased Transparency, Consistency, and Fairness in Pretrial Bargaining Under the Foreign Corrupt Practices Act, Hastings Business Law Journal, 10, 2014, pp. 347-378 (asserts that "given the enormous leverage in the negotiation, the DOJ can oftentimes negotiate favourable prosecution agreements, whose terms can include large financial penalties, significant internal business reforms, and cooperation in pursuing the company's individuality culpable directors, executives, managers, and/or employees"). 
guidelines to steer them towards corporate compliance ${ }^{11}$ while shaping a good corporate citizenship ${ }^{12}$.

Against this background, the Chinese judiciary must assist corporations in navigating through the sinuous road of corporate compliance as to both avoid corporate criminal liability and to lay down the foundations upon which stands an ethical corporate culture that wishes the latter away. It boils down to nudge corporations towards more rational (therefore) legal avenues - the gist of behavioral ethics ${ }^{13}$, which stands as a burgeoning body of cognitive research ${ }^{14}$ of paramount importance in the breadth and scope of corporate criminal procedural law $^{15}$. An overriding goal that both SPP Guiding Cases and Supreme People's Court of China Judicial Interpretations have neither lost sight of nor have overlooked.

With this context in place, this paper seeks to map the path forward to shaping a new corporate criminal procedural law - an utterly uncharted and untapped universe in Mainland China - that draws on

11 But see: Bird, Robert C./Park, Stephen Kim, The Domains of Corporate Counsel in an Era of Compliance, American Business Law Journal, 53, 2016, pp. 203-229 (stating that companies 'directors remain fully accountable for corporate compliance nonetheless).

12 But see: Tippet, Elizabeth/Alexander, Charlotte S./Eigen, Zev J., When Timekeeping Software Undermines Compliance, Yale Journal of Law and Technology, 19, 2017, pp. 1 and ff (alerting to the harmful and faulty software can tarnish - in that they bypass and circumvent - entire corporate compliance programs).

13 Kaplan, Jeffrey M., Compliance Programs and the Corporate Sentencing Guidelines, \& 6: 21. Westlaw: Thomson Reuters, 2021 (arguing that "behavioural ethics has potentially significant implications for many aspects of compliance and ethics programs").

14 Haugh, Todd, Nudging Corporate Compliance, American Business Law Journal, 54, 2017, pp. 683-705 (positing that behavioral ethics boasts multitudinous implications for criminal procedure law while laying down the foundations upon which stands a batch of unnumbered behavioural compliance strategies).

15 Murphy, Diana E., The Federal Sentencing Guidelines for Organizations: A Decade of Promoting Compliance and Ethics, Iowa Law Review, 87, 2002, pp. 697-711 (arguing that Organizational Guidelines resonate with, and are the encapsulation of, an enticement (encouragement?) of "good corporate citizenship" which oftentimes constitutes the breeding ground for both behavioural ethics and effective corporate compliance programs). 
the robust pillars of procedural fairness and procedural justice: the cornerstones of due process.

This paper proceeds in four parts. Part I will be geared towards briefly establishing an interplay between corporate governance and a tobe-avoided corporate criminal liability. Part II fleshes out the procedural legality turn in People's Republic of China criminal procedure law catalyzed by SPP Guiding Cases while canvassing the rationale behind such a seismic shift. Part III shines a keen light on the cultural and legal changes (from both a perspective and prospective standpoint) set in motion by SPP Guiding Cases while parsing its impact on corporate criminal procedure law. Part IV wraps up this long-winded paper by summarizing its main findings.

\section{THE DESIGN OF EFFECTIVE CORPORATE COMPLIANCE PROGRAMS MATTERS INDEED: THE INTERPLAY BETWEEN CORPORATE GOVERNANCE AND THE MINIMIZATION OF CORPORATE CRIMINAL LIABILITY}

China is a behemoth country whose cultural background rests upon robust Confucianism ${ }^{16}$ traits $^{17}$. The sweeping aims of both preserving social harmony ${ }^{18}$ and maintaining social stability are lodged

16 Shiga has contended that civil justice in imperial China, which was deeply embedded in Confucianism traits, stood as a quintessential form of 'Kadi' justice in which magistrates would arbitrarily (thus willingly) decide (and dispose) cases anchored in a vast array of Confucian moral principles as opposed to statutory law. Shiga, S., A Study of Chinese Legal Culture Focusing on the Litigation Landscape, Journal of Comparative Law, 3, 1988), pp. 18-26 [滋贺秀三 “中國法文 化的考察以訴訟的形態為素材” 1988年第3期 《比较法研究》18-26]. See also: Chan, Peter Chi Hin, “The Enigma of Civil Justice in Imperial China, A Legal Historical Enquiry”, Maastricht Journal of European and Comparative Law, 19, 2012, pp. 317-337 (whose research I have been following very closely).

17 In French doctrine, Escarra, Jean, Le droit chinois. Paris: Dalloz, 1918, pp. 9-12 (highlights the role of customary law and Confucianism «Rites» in Imperial China).

18 Confucianism has had a raging (and therefore profound) impact on dispute resolution in Hong Kong. See: Holloway, David,/Lin, Feng/Li, Linda Chelan/ Zheng, Xiaohe / Kwok, Mantak, Strengthening Hong Kong's Position as an Arbitration Hub in the Belt and Road Initiative, International Arbitral Law Review, 21,4, 2018, pp. 106-107 ("Hong Kong has a long history of providing 
at its core ${ }^{19}$. Such an interplay, albeit seemingly unimportant at first blush, has a sizable impact on dispute resolution ${ }^{20}$ in Mainland China ${ }^{21}$. The design of effective corporate compliance programs (企業合規項目) aimed at drastically abridge (in an ideal world upend) corporate criminal liability (公司刑事責) is not by all means an exception. To portray such a tandem, light must be cast upon the intrinsic linkage between a lawabiding corporate governance (公司治理) and a to-be-avoided corporate criminal liability ${ }^{22}$.

arbitration services. In the early years of Hong Kong as trade port, the traditional Chinese preference for informal justice over litigation was deep-rooted in the local communities").

19 But see: Chan, Peter Chi Hin, The Position of Mediation in Contemporary Chinese Civil Justice: A Proceduralist Perspective, PhD dissertation in Civil Procedure Law, 2016, 65 (this learned scholar has drawn attention to the artificiality of this concept nonetheless: "The fabric of Chinese society is not enjoying the kind of stability and true harmony that could provide sustainability in the country's development [...] Under the leadership of Hu Jintao, the CCP emphasized the need to maintain a «socialist harmonious society with a view to harness the economic opportunities through a sustainable and low-risk social engineering strategy. The artificiality of the concept of a «socialist harmonious society» is perhaps best illustrated in the way the leaders of the Chinese judiciary (especially during Wang Shengjun's era) promoted the use of mediation to handle rising conflicts in the country") (italics added).

20 Huang, Jiali (Keli), One Country, Two Systems: Hong Kong's Unique Status and the Development and Growth of Arbitration in China, Cardozo Journal of Conflict Resolution, vol. 18, n. ${ }^{\circ}$ 2), 2017, p. 423 (argues that "China has maintained a negative bias against litigation and the social disharmony that accompanies it. This cultural tradition carried over to the sphere of international commerce and trade") (italics added).

21 Chan, Peter Chi Hin, Civil mediation in imperial, republican and modern-day China Historical and cultural norms under the traditional Chinese legal order, The Legal History Review, 85, 2017), pp. 577-602 (578) (notes that "disputes should be resolved through mediation to preserve social harmony. Under the Confucian ideology, disputes of a civil nature should be settled through conciliatory means so that the amicable relations of the disputants could be maintained. Litigation should be the last resort") (italics added).

22 On corporate criminal liability: BRITO, Teresa Quintela de. Domínio da organização para a execução do facto: responsabilidade penal de entes coletivos, dos seus dirigentes e "atuação em lugar de outrem”, Vols. I e II, Dissertação de doutoramento, Faculdade de Direito da Universidade de Lisboa, 2012; - Tratado sobre Compliance Penal. Responsabilidad penal de las personas jurídicas y modelos de organización y gestión, Juan-Luis Gómez Colomer (Org.), Valencia: Tirant lo blanch, 2019. 
The increasing importance (and dire need) of a law-abiding corporate governance is tightly interlocked with China's fastpaced economic growth. China was blessed by an unparalleled and unprecedented economic growth in previous decades, which has sent ripples across the world ${ }^{23}$. There have been calls (often wrapped in opaqueness and beset by the devilishly harmful virus of unfairness) positing that China's judicial system is woefully ill-prepared to offer a befitted protection to the creditors ${ }^{24}$ though. Such an in-dire-needto-be-awarded protection to creditors stands at the heart of a soughtafter law-abiding corporate governance to spawn effective corporate compliance programs, which, in crux, aim to avoid corporate criminal liability altogether. A law-abiding corporate governance legal framework ${ }^{25}$ is thus closely connected with the sought-after instillment of trust

${ }_{23}$ "How China Runs the World Economy", The Economist (July 28, 2005), available at: https://www.economist.com/leaders/2005/07/28/how-china-runsthe-world-economy (accessed: 03.03.2021).

24 World Bank Group, Doing Business 2019, Training for Reform, Economy Profile: China, World Bank Group, 3, 2019, , available at: https://www.worldbank.org/content/dam/doingBusiness/media/Annual-Reports/English/ DB2019-report_web-version.pdf (accessed: 03.03.2021) (stressing that China's Judicial System ranks very low from the efficiency point of view)). This phenomenon has both a unwholesome and unfitting effect: the depradation of trust theory (Vertrauenstheorie), which runs through the backbone of any legal system. In general, about the utmost relevance of trust in contract relationships, chiefly from the culpa in contrahendo point of view. See: in German doctrine: Von Jhering, Rudolf, Culpa in contrahendo" oder Schadensersatz bei nichtigen oder nicht zur Perfektion gelangten Verträgen, Gesammelte Aufsätze aus den Jahrbüchern für die Dogmatik des heutigen römischen und deutschen Privatrechts, Jena, 1, 1981, pp. 327-425. In Italian doctrine: Marasco, Gerardo, La rinegoziazione del contrato - strumenti legali e convenzionali a tutela dell' equilibrio negoziale. Padova: Cedam, 2006, pp. 18 e ss and passim.

China has made significant headway in chiming in its commercial law with the baseline standards laid down by World Trade Organization (WTO) nevertheless. . See: Prime, Penelope B., China Joins the WTO: How, Why, and What Now?, Business Economy, Business Economy, 37, 2002, pp. 26-32, available at: https://era.ong/wp-content/uploads/china-joins-wto-1.pdf (access: 03.03.2021) (posits that China has made a gargantuan effort to revamp the backbone of its commercial law). 
$(\text { 信任 })^{26}$, trustworthiness (誠信度 $)^{27}$ and efficiency (效率) ${ }^{28}$ on (of) a given system of administration of justice (既定的司法行政) with a view to wear down and (ideally) cast off the gruesome effects of white-collar crime (白領犯罪) ${ }^{29}$ and economic-financial criminality (經濟金融犯罪) of which corporate criminality (公司刑事責任) stands as a capstone.

26 Such findings are consistent with a piece of empirical evidence. See: Magalhães, Pedro C. /Garoupa, Nuno, Judicial Performance and Trust in Legal Systems: Findings from a Decade of Surveys in 20 European Countries, Social Science Quarterly, 2020, pp. 1 and ff(on the relationship between case's disposition time and the trust in their legal system, the findings arising out this survey have shown that "the longer the time that lower courts take, on average, to dispose of pending cases, the lower is the public's trust in their legal system").

27 A research conducted on this purview has pinpointed an intrinsic linkage between Justice, Trust and Trustworthiness, thereby throwing a fresh light on their respective roles. See: Colquitt, Jason A./Rodell, Jessica B., Justice, Trust, and Trustworthiness: A Longitudinal Analysis Integrating Three Theoretical Perspectives, Academy of Management Journal, 54, 2011), pp. 1183 ff.

28 But see: Global Pound Conference Global Trends Report from Herbert Smith Freehills and PwC, Global Pound Conference: Global Data Trends and Regional Differences Series, available at: https://www.pwc.com/gx/en/forensics/ gpc-2018-pwc.pdf (access: 08.07.2021) ("when the global data was segmented by regions it was clear that efficiency was the key priority in all regions except Asia, where the key priority was the certainty and enforceability of outcomes. This may indicate an important underlying difference about how stakeholders in Asia perceive non-adjudicative dispute resolution processes") (italics added).

29 The painstaking headaches that the criminal procedure law evangelists have been enduring for long-winded span of time are not to stave off anytime soon. On the opposite pole, they are bound to flare up anytime soon. Mostly on the account the threadbare RisikoGesellschaft (society of risk, sociedad de riesgo or sociedade do risco).See in Spanish doctrine on the interplay between sociedad de riesgo and the challenges arisen from it: Sánchez, Bernardo Feijoo, Sobre la «administrativizácion» del Derecho penal en la «sociedad de riesgo»: un apunte sobre la política criminal a princípios del diglo XXI, Derecho Y Justicia Penal en el Siglo XXI. Liber Amicorum en Homenaje al Profesor Antonio González-Cuéllar Garcia. Madrid: Ed. Colex, 2006, pp. 137 ff and passim. On the perceived hazard that criminal law becomes a Symbolisches Strafrecht: Hassemer, Winfried, Symbolisches Strafrecht und Rechtsgüterschutz, NSTZ, München, 89, 2014, pp. $557 \mathrm{ff}$ and passim. It is believed that RisikoGesellschaft is putting the fundamental tenets of criminal law at odds. The sub-prime crisis of 2008 (whose noxious effects are shaping up to be compounded by the worldwide pandemic spawned by Covid-19) laid bare the insufficiency (the lackluster of, coupled with, the dearth of) basic assumptions of criminal procedure law to tackle transnational and globalized white-collar crime. Against the backdrop of which 
Against this background, this paper seeks to shine a keen light on the candent challenges that lie ahead for corporate criminal procedure law in Mainland China.

In addition to that, light will be cast upon the procedural features that China's corporate criminal procedure law must embrace in order to tackle effectively the scourge of corporate criminal liability.

\section{The PROCEDURAL Legality tURN IN THE CRIMINAL PROCEDURAL law of People's Republic of China catalyzed by the Supreme People's Procuratorate Guiding Cases: Introduction}

As hinted above, People's Republic of China legal landscape is changing ${ }^{30}$. Such a thrust towards a sought-after change has pervaded (in that ran through) several legal areas ${ }^{31}$. Along with these winds of change came a yearning crave to ameliorate the backbone of China's criminal

a group of learned scholars boded the system's failure or (interchangeably) its decay (Systemversagen). See in Portuguese doctrine: Dias, Augusto Silva, O Direito Penal como instrumento de superação da crise económico-financeira: estado da discussão e novas perspectivas, Anatomia do Crime, Revista de Ciências Jurídico-Criminais, 0, 2014, pp. pp. 45-73. See in German doctrine: Naucke, Der Begriff der politischen Wirtschaftsstrafrecht - Eine Annährung, LIT, 2012, pp. 8-72. See in Spanish doctrine: Rivas, Garcia, "Reflexiones sobre la responsabilidad penal en el marco de la crisis financeira”, Demetrio Crespo (Dir.), Crisis financiera y Derecho Penal Económico, 2014, pp. 19 ff. .

30 Scholars have neither been coy nor bashful when it comes to (in that they have not refrain themselves from) bringing forward suggestions for improving the Chinese legal system. Against this background, it should amount to a startling finding that proposals aimed at accomplishing such a laudable goal abound accordingly. See: Hawes, Colin, How Chinese Judges Deal with Ambiguity in Corporate Law: Suggestions for improving the Chinese Case Precedent System, Australian Journal of Asian Law, 19, n. ${ }^{\circ}$ 1, 2018, pp. 1-22.

31 The recent changes made in China's corporate bankruptcy law stand as a living testament of the ongoing effort to improve the overall functionality of internal laws. See: Shaowei, Lin, The Empirical Studies of China's Enterprise Bankruptcy Law: Problems and Improvements, in: International Insolvency Review, 27, 2018, pp. 77-85. The same goes to the insolvency law. See: Steele, Stacy et al., Trends and Developments in Chinese Insolvency Law: The First Decade of the PRC Enterprise Bankruptcy Law, in: The American Journal of Comparative Law, 66, 2018, pp. 669 e ss. 
procedure law ${ }^{32}$. In a nutshell: to infuse a culture of legality to its criminal procedure law. Which begs the questions: how did we get here?33 What was the rationale behind this legality turn in People's Republic of China? What made it possible? What is the impact (if any) that the foregoing legality turn has had on the remit of corporate criminal procedure law? To palatably (hence: thoroughly) answer these sizzling hot questions one must flesh out the pivotal role played by the Guiding Cases issued by the Supreme People's Procuratorate back in 2010, which were paramount as to morph the Chinese prosecutor culture while catering to the creation of a brand new dispute resolution mindset from scratch.

Such a paradigm shift has heralded the break of dawn of a new era in People's Republic of China criminal procedure law. From which a string of legality-driven corollaries can be with withdrawn, as further shown below. More on this later.

Unlawful arrests and wrongful convictions ${ }^{34}$, a murky shadow of a not-so distant past ${ }^{35}$, which generally worked to the advantage of prosecutors $^{36}$ (the whooping majority of whom harboured eerily malevolent attitudes towards a cohort of defendants under the guise of, and mostly pursuant of, striking hard campaigns against crime ${ }^{37}$ ) paints the gloomy picture of criminal proceedings which have fallen seriously short of matching the fundamental tenets of legality. Which has spawned unfettered

32 Finder, Susan, China's Evolving Case Law System in Practice, Tsinghua China Law Review, 9, 245, 2017, pp. 253 and ff (describes China's case law system in action while making suggestions eyeing its overall improvement).

33 The sheer bulk of answers in this regard can be found in an excellent piece of research such as: Trevaskes, Susan, Courts and Criminal Justice in Contemporary China. Lanham, United States of America: Lexington Books, 2007, pp. 1-227.

34 Jiahong, He, Case Study on the Causes of Wrongful Conviction in Chinese Criminal Proceedings, Frontiers of Law in China, 10, 2015, pp. 671 and ff.

35 Shiyuan, Huang, Chinese Wrongful Convictions: Causes and Prevention, University of Cincinnati Law Review, 80, 2012, pp. 1219 and ff.

36 Where judicial independence and procedural chivalry falters and therefore fizzles out, the door of procedural mayhem is ajar slightly. Take the abhorrent (and gruesome) situation in Egypt further a failed transition to democracy as to-be-frowned upon example. See: Aziz, Sarah F., Independence Without Accountability: The Judicial Paradox of Egypt's Failed Transition to Democracy, Penn State Law Review, 120, 2016, pp. 100 and ff.

37 Trevaskes, Susan, Courts and Criminal Justice in Contemporary China, cit. 
public distrust ${ }^{38}$ espoused to a widespread outcry with the administration of justice in People's Republic of China ${ }^{39}$. It is by no means flummoxing that a groundswell of grievances demanding immediate reform ${ }^{40}$ in the purview of criminal procedure law ${ }^{41}$ sprouted all over People's Republic of China ${ }^{42}$. As pointed out above, a paradigm shift was keenly needed.

Such a paradigm shift was set in motion by the Guiding Cases issued by the Supreme People's Procuratorate back in 2010, whose fundamental tenets will be skeletally remarked upon in the subsequent sections of this paper.

\subsection{The impact of Supreme People's Procuratorate Guiding Cases on the CREATION OF a LEGALITY-DRIVEN CRIMINAL PROCEDURE LAW IN CHINA: BRIEF (THUMBNAIL) SKETCH}

Given the (boundless?) expansion of the respondeat superior liability ${ }^{43}$, there is (was) a perceived need to bestow upon corporations the

38 Pei, Minxin, China's Crony Capitalism: The Dynamics of Regime Decay. Cambridge: Massachusetts, Harvard University Press, 2016.

39 Fu, Hialing, China's Striking Anticorruption Adventure: A Political Journey toward the Rule of Law?, The Beijing Consensus? How China Has Changed the Western Ideas of Law and Economic Development, Chen, Weitseng (Editor). Cambridge: Cambridge University Press, 2017, pp. 249-274.

40 Lin, Xifen/Shen, Wei, Reforms to China's pretrial detention system: the role of the procuratorate, International Journal of Law, Crime and Justice, 44, 2016, pp. 183-211.

41 Hawes, Colin, Improving the Quality of the Judiciary in China: Recent Reforms to the Procedures for Appointing, Promoting \& Discharging Judges, Appointing Judges in an Age of Judicial Power: Critical Perspectives from Around the World, K. E. Malleson/Peter H. Russell (Editors). Toronto: University of Toronto Press, 2016, pp. 395-419.

42 Chen, Jianfu, Criminal Law and Criminal Procedure Law in the People's Republic of China: Commentary and Legislation. Leiden: Martinus Nijhoff Publishers, 2016.

43 Larkin, Paul J./Seibler, John-Michael, All Stick and No Carrot: The Yates Memorandum and Corporate Criminal Liability, Stetson Law Review, 46, 2016, pp. 7-8 (emphasizes that "bottom line is that a corporation is criminally, strictly, and vicariously liable for whatever crimes corporate personnel commit on company time unless they are on a frolic and detour for their own exclusive, personal benefit"). 
universe of procedural defences originally allotted to individual defendants in criminal procedure law $^{44}$. In a nutshell: procedural fairness and procedural justice, which, taken together, were brought about by the foregoing Guiding Cases $^{45}$ issued by the Supreme People's Procuratorate as far back as 2010. The Guiding cases ${ }^{46}$ resonate (d) with the protection ${ }^{47}$ of basic due process ${ }^{48}$ rights. The issuance of guiding cases ${ }^{49}$ coincided with a

44 Such as fact-finding. Generally: Priester, Benjamin J., From Jones to Jones: Fifteen Years of Incoherence in the Constitutional Law of Sentencing Factfinding, University of Toledo Law Review, 47, 2016, pp. 413 and ff.

45 NG, Michael H. K., Legal Transplantation in Early Twentieth-Century China. Abingdon-on-Thames: Routledge, 2016, pp. 1-188 (1-3) (posits that Republic China (1912-1949) obliterated imperial legal codes and the accompanying case compilation cobbled together throughout that epoch. The groundswell of, and the epoch of, legal transplants in Mainland China would follow suit).

46 Limmer, Jocelyn E. H., "China's New "Common Law”: Using China's Guiding Cases to Understand How to do Business in the People's Republic of China”, Willamette Journal of International Law and Dispute Resolution, 21, 2013, 96113 (argues that, with the creation of guiding cases legal mechanism, the Asian giant - China - is heading towards the "recognition of Chinese legal precedent"). Unsurprisingly, guiding cases are tightly interlocked with political ideology and arouse controversy as to what role is to be ascribed to courts in China. See: Chinese Common Law? Guiding Cases and Judicial Reform, Harvard Law Review, 129, 2016, p. 2234 ("China's new guiding cases system has generated an unusual amount of attention and optimism. Still, many challenges remain. Low rates of case issuance and usage will require sustained effort from policymakers, as will the more politically delicate task of defining the system's scope of authority amid competing institutional and ideological interests. The future of guiding cases will therefore hinge upon the political savvy of various institutional actors, as well as the Party-state's still-evolving vision of what role courts should play in ordering Chinese society").

47 Hawes, Colin, "Transforming the Culture of Chinese Prosecutors Through Guiding Cases", New Criminal Law Review, 23, 2020, p. 196 (argues that "fifteen sets of Guiding Cases issues by the Supreme People's Procuratorate since 2010 promote an unprecedented change in Chinese procurator culture away from "striking hard" to substantive protection of criminal suspects 'rights and exclusion of tainted evidence. They reinforce criminal procedure reforms since 2010 by demonstrating how procurators should protect innocent people against wrongful convictions and police brutality").

48 Alexy, Robert, Theorie der Grundrechte. Franfurt am Main: Suhrkamp, 1996 (referring to the two-layered nature of fundamental rights, such as the access to justice, both as a rule and as a principle).

49 Zhang, Taisu, “The Pragmatic Court: Reinterpreting the Supreme People's Court of China", Columbia Journal of Asian Law, 25, 1, 2012, 8 (emphasizes 
generational personnel overhaul within People's Republic of China legal apparatus $^{50}$. Its overriding goal was (is) to promote judicial practices ${ }^{51}$ commensurate with the fundamental tenets of a healthy rule of law. Which is nothing but formulaic. Rule of law, being both a catch-all concept and all-encompassing idea ${ }^{52}$, amounts to a beacon (and foremost as a lighthouse) of justice ${ }^{53}$ which defendants (including corporations) tend to rely upon in criminal proceedings ${ }^{54}$. A lesson that the great bulk of Guiding cases has neither lost sight of nor has forsaken.

that guiding cases have a sort-of "stare decisis-like authority" which chimes in with its surrounding rhetoric).

50 Hawes, Colin, "Transforming the Culture of Chinese Prosecutors Through Guiding Cases", cit.

51 Waldron, Jeremy, The Rule of Law and the Importance of Procedure, New York Public Law and Legal Theory, 2010, p. 4 (noting that "the Rule of Law is violated when due attention is not paid to these procedural matters or when the institutions that are supposed to embody these procedures are undermined or interfered with").

52 Whilst further utterances on the matrix of Rule of Law fall beyond the breadth and scope of this article, one must not be oblivious of the fact that the thrust to Deglobalizing Rule of Law is underway. See: Bussani, Mauro, "Deglobalizing Rule of Law and Democracy: Hunting Down Rhetoric Through Comparative Law", The American Journal of Comparative Law, 67, 2019, pp. 701-744 (701) (contending that the thrust to Deglobalizing Rule of Law is interwoven with thrust to take heed of "well-known differences that run through cultures and traditions". In spite of which, "the West has never stopped trying to export its own law into the rest of the world"). Unsurprisingly, there have been educated calls to take heed of the pinpointed cultural and legal differences by, in the case of China, allow for a "Socialist Rule of Law". See: Chinese Common Law Guiding Cases, Harvard Law Review, 129, 2016, p. 2213.

53 Allison, J. W. F., "Turning the Rule of Law into an English Constitutional Idea, May, C./Winchester, A. (Eds.), The Edward Elgar Handbook on the Rule of Law. Cheltenham, United Kingdom: Edward Elgar, 2018; Lino, Dylan, "The Rule of Law and the Rule of Empire: A.V. Dicey in Imperial Context", The Modern Law Review, 81, 5, 2018, passim (highlighting the idea according to which the rule of law is much more ubiquitous globally today than ever before, and owes a lasting debt to the ground-breaking work of Victorian legal theorist A. V. Dicey).

54 Raz, Joseph, "The Rule of Law and its Virtue", The Authority of Law: Essays on Law and Morality, Essays on Law and Morality. Oxford: Clarendon Press, p. 224 (stating adamantly that the Rule of Law is aimed at ebbing and cushioning the hazards of functional abuse from those in power. On that account, Raz 
Against this background, the Guiding Cases strived (and are still striving) to ensure procedural due process in criminal procedure law in People's Republic of China. To that end, the Supreme People's Procuratorate (SPP) ${ }^{55}$ has issued a batch of Guiding Cases to stamp out (and thus halt) prosecutorial misconduct while catering to the creation of a robust culture of protection of basic procedural rights premised in an unshakeable foundation of legality. Against the backdrop of which both prosecutorial (and police misconduct), which, taken together, have given rise to a sheer number of wrongful convictions in a not-so distant past, are to be weeded out (and therefore swept aside) from the realm of criminal procedure law.

The Guiding cases therefore do not belie the, in that they do not fall short of matching the, propelling force that is deeply woven into its fabric: ensure social stability ${ }^{56}$ and social harmony ${ }^{57}$ in a gargantuan country that would be otherwise ungovernable absent such procedural guidelines.

Which prompts the question: why are the foregoing procedural guidelines so momentous in China's modern criminal procedure law? There is an eye-catching cluster of Guiding Cases that epitomize the importance of these procedural guidelines as to strive for overall fairness

posits that "the law inevitably creates a great danger of arbitrary power - the Rule of Law is designed to minimize the danger created by the law itself... Thus the (R)ule of (L)aw is designed to minimize the danger created by law itself...Thus the (R)ule of ( $\mathrm{L}$ )aw is a negative virtue...the evil which is avoided is evil which could only have been caused by the law itself"). Converging: Taekema, Sanne, The Procedural Rule of Law: Examining Waldron's Argument on Dignity and Agency, Jahrbuch für Recht und Ethik, Band 21, 2013, pp. $133 \mathrm{ff}$ (arguing that the «Rule of Law is understood as the restraint law puts on those in power. The famous phrase: Rule of Law, not man, encompasses the idea that a person in a position of power should not be left to his own device, but should be subject to legal limitations») (italics added).

55 A selection of SPP of a batch of Guiding Cases in Chinese can be found in: https://www.chinalawtranslate.com/en/spp-guiding-cases/ (access: 23.08.2021).

56 Trevaskes, Susan, Death sentencing for stability and harmony, The Politics of Law and Stability in China. Cheltenham Glos, United Kingdom: Edward Elgar, 2015, pp. 127-151.

57 Chen, Xingliang, Guiding Cases for China's Death Penalty, The Death Penalty in China: Policy, Practice, and Reform, Liang, Bin/Lu, Hong (Ed.). New York: Columbia University Press, 2015, pp. 187-213. 
in China's criminal procedure law. Insofar Guiding Cases play a key role in spawning procedural justice (and procedural fairness) on the operation of the Chinese criminal system, they should be extended to corporate criminal procedure law. Let us take a bird's eye view at them.

Guiding Cases are mostly related with the collection of evidence (the great bulk of which concerned with the procedural aspects of death penalty). Whilst they are bereft of binding effect in a legal sense, Guiding Cases (either those issued by the SPP or those issued by the Supreme People's Court (SPC) $)^{58}$ bear on the judicial operators' functional activity ${ }^{59}$.

Guiding Cases, being a politically-charged tool (that at first blush ${ }^{60}$ run counter the French-laden principle of separation of powers ${ }^{61}$ ) to

58 Zhang, Mo, Pushing the Envelope: Application of Guiding Cases in Chinese Courts and Development of Case Law in China, Washington International Law Journal, 26, n. ${ }^{\circ} 2017$, pp. 268 and ff.

59 See: Deng, Jinting, The Guiding Case System in China's Mainland, Frontiers of Law in China, 10, 2015, pp. 449 and ff.

60 But see: Zhenjie, Zhou, Corporate Crime in China: History and Contemporary Debates. New York: Routledge, 2016, p. 1-204 (88) (posits that the Chinese judiciary "is quite different, if not completely different, from that in Western countries that have adopted the principle of separation of powers; it is more administrative than judicial in nature").

${ }^{61}$ See in French doctrine, Montesquieu, L'Espirit des Lois, Une édition électronique réalisée à partir du livre Montesquieu, De l'esprit des lois (1758). (Texte de 1758, dernier état du texte revu par Montesquieu. L'orthographe a été modernisé et la ponctuation légèrement, mais non la graphie. Édition établie par Laurent Versini, professeur à la Sorbonne. Paris: Éditions Gallimard, 1995, 2 vols: vol I: pp. 1 à 604; vol. II: pp. 605 à 1628.) Collection folio Essais) (noting that law, when coupled with the one of the bedrocks of Constitutional Law (which is precisely the principle of separation of powers) spawns the assertion according to which: «Les Lois, dans la signification la plus étendue, sont les rapports nécessaires qui dérivent de la nature des choses» (italics added). See in Swiss-French doctrine: Rousseau, Jean Jacques, Du Contrat Social, ou Principes du Droit Politique, Bibliothéque publique et universitaire de Geneve (première version); "Le manuscrit contenant la version définitive du Contrat social qui a été imprimée a disparu." le Pléiade édition t. III, p.1866. Publication, Amsterdam, février-mars 1762, Marc Michel Rey, etc.; le Pléiade édition t. III, pp. 347-470, 1866-1874. == Du Peyrou/Moultou 17801789 quart édition; t. I, (1782): 187-360 (argues that the principle of separation of power bears close resemblance with the sought-after preservation of the fabric of, and with the matrix of, de l'état civil, which is bound to herald a new era brimming with social stability as opposed to the abhorrent état de nature, which is amenable to sap such social stability and wreak havoc in a 
beget both procedural fairness and procedural justice, seek to nudge ${ }^{62}$ prosecutors towards more legal avenues ${ }^{63}$ in criminal procedure law ${ }^{64}$. It is thus hardly befuddling that prosecutors are keenly urged to uphold the public interest (mirrored in the creation of clean, seamless and fuss-free criminal proceedings) while quelling abuses perpetrated by unscrupulous officials and brushing aside shady corporate interests that run afoul with the general interest of People's Republic of China.

given jurisdiction. Against this backdrop: «De l'État civil. Ce passage de l'état de nature à l'état civil produit dans l'homme un changement trèsremarquable, en substituant dans sa conduite la justice à l'instinct, \& donnant à ses actions la moralité qui leur manquoit auparavant». (italics added). But see: Lin, Lin, "Corporate Crime in China: History and Contemporary Debates by Zhou Zhenjie”, Singapore Journal of Legal Studies, 2015, pp. 285-287 (285) (posits that "comparing the functions of the People's Court and the process of appointing judges with that in Western countries" (....) it is somewhat acceptable that the principle of the separation of powers in People's Republic of China runs in nonconformity with core values nurtured by western jurisdictions (such as the profusion of political parties) given the "current one-party political situation in China").

${ }_{62}$ Sunstein, Cass R., The Ethics of Nudging, Yale Journal on Regulation, 32 (2/6), 2015, (emphasizing that "all over the world, governments are using nudges as regulatory tools. If welfare is our guide, much nudging is actually required on ethical grounds, even if it comes from government") (italics added.

${ }_{63}$ Sunstein, Cass R., The Ethics of Nudging, cit., 415 (noting that "both nudges and choice architecture are inevitable, and it is therefore pointless to wish them away"). See also: Jolls, Christine, Debiasing Through Law and the First Amendment, Stanford Law Review, 67, 2015, pp. 1411 ff (arguing, however, that compulsory warnings are amenable to quash both autonomy and dignity). This phenomenon amounts to a Behavioural Law and Economics' creation deemed as Debiasing through Law. See: Jolls, Christine/Sunstein, Cass R., Debiasing Through Law, John M. Olin Program in Law and Economics Working Paper n. ${ }^{\circ} 225,2004$, p. 1 (assert that "Human beings are often boundedly rational. In the face of bounded rationality, the legal system might attempt either to "debias law", by insulating legal outcomes from the effects of boundedly behaviour, or instead to "debias through law" by steering legal actors in more rational directions") (italics added).

64 Thaler, Richard H./Sunstein, Cass R., Nudge: Improving decisions about health, wealth, and happiness. London: Penguin Books, 2009 (by nudging Chinese prosecutors in the direction the lawmaker sees procedurally fit, like a taintless criminal proceeding, which amounts to a cloak under which the both procedural fairness and procedural justice are wrapped). 
No surprise springs from the fact that Guiding Cases resonate with a fine-grained cost-benefit analysis ${ }^{65}$ against the backdrop of which a delicate balance has been struck between private interests (grasp procedural fairness and procedural justice, which must be bestowed upon defendants in criminal procedure law) and general interests ${ }^{66}$ (clutch social stability and social harmony in China while simmering down a lurking social unrest with the administration of criminal justice).

To cater to that, the great bulk of Guiding Cases cover a broad spectrum of procedural issues that are generally applicable to criminal proceedings ${ }^{67}$. Amongst which stands procedural guidelines on crucially important aspects of criminal procedural law such as due process, procedural legality, nemo tenetur se ipsum accusare ${ }^{68}$, and a fair treatment to be ascribed to defendants (ideally) with no qualms whatsoever.

65 Cost-benefit Analysis has been garnering a great deal of attention in the United States of America. Fleshing out its overall content falls well outside the breadth and scope of this paper nonetheless. See: Sunstein, Cass R., The Real World of Cost-Benefits Analysis: Thirty-Six Questions (and almost as many answers), Columbia Law Review, 114, n. ${ }^{\circ}, 2014$, pp. 177 ff; Bayefsky, Rachel, Dignity as a value in Agency Cost-Benefit Analysis, Yale Law Journal, 123, 2014, pp. 1740 and ff; Coates, John C., Cost-Benefit Analysis of Financial Regulation: Case Studies and Implications, Yale Law Journal, 124, 2015, pp. 882-911; Posner, Eric A./Weyl, E. Glen, Cost-Benefit Analysis of Financial Regulations: Response to Criticisms, Yale Law Journal, 124, 2015, pp. 246-265 (canvassing the foundations to the interplay between cost-benefit analysis, human dignity and government decisions to ensure the public interest).

Whenever general interests and private interests are weaved together (or are in the process of being meld or cognate), the earth-shattering work of Kant crops up. See: Kant, Immanuel, Lectures and Drafts on Political Philosophy, Rauscher, Frederick/Westphal, Kenneth R. (Editors). Cambridge: Cambridge University Press, 2016, pp. 73-180 (a series of Kant's lectures based upon notes taken by the Gottfried Feyerabend in which the former has set forth the seminal notion of Right).

Hawes, Colin, “Transforming the Culture of Chinese Prosecutors Through Guiding Cases”, cit.

Without which there is neither procedural fairness nor procedural justice (let alone due process) to be accounted for, much less to be remarked upon. See: Andrade, Manuel da Costa, Nemo tenetur se ipsum accusare e direito tributário. Ou a insustentável indolência de um acórdão (n. ${ }^{\circ} 340 / 2013$ ) do Tribunal Constitucional, Revista de Legislação e Jurisprudência, Ano $144 .^{\circ}$, Novembro-Dezembro de 2014, N. ${ }^{\circ}$ 3989. Coimbra: Coimbra Editora, 2015, pp. 144 e ss. In German doctrine: KASISKE, Die Selbstbelastungsfreiheit 
Anchored in, and underpinned by, robust foundations of justice as fairness ${ }^{69}$ and human dignity ${ }^{70}$, the Guiding Cases therefore provide clear and agreed-upon procedural guidelines to prosecutors as to promptly oust illegally obtained evidence in criminal proceedings. Chiefly evidence gleaned through utterly unlawful means. Such as torture and physical violence in an overarching sense. Which is clearly set out in SPP Guiding Case $27^{71}$.

SPP Guiding Case 27 thus stands as the capstone of a mature and full-fledged criminal system of justice, which is currently grounded in the pillars of justice as fairness ${ }^{72}$. Strikingly, the earth-shattering SPP

im Strafprozess, JuS, 2014, pp. 23-26; Zuck, R., Faires Verfahren und der Nemo tenetur-Grundsatz bei der Besuchsüberwachung zu BGH, Urteil v. 29.04.2009, Juristische Rundschau, 2010, pp. 18-27.

69 On the momentous importance of justice as fairness in criminal procedure law. See: Rawls, John, A Theory of Justice, $2^{\text {nd }}$ edition. Cambridge, Massachusetts: Belknap Press: An Imprint of Harvard University Press, 1999, 2019 (reprint): 1-540. Concurs: Dworkin, Ronald, Law's Empire, Cambridge. Massachusetts: Belknap Press, 1986, 2016 (reprint), passim.

70 On the paramount importance of human dignity. See in Portuguese doctrine: Miranda, Jorge, "Os valores permanentes da Constituição portuguesa”, in: Julgar, n. ${ }^{\circ}$ 29, Maio-Agosto 2016. Coimbra: Almedina, 2016, pp. 45-47; Novais, Jorge Reis, A dignidade da pessoa humana, Coimbra, Almedina, vol. II 2016, passim. In French doctrine: Fierens, Jacques, "La dignitè humaine comme concept juridique", in: Journal des tribunaux, 121, 2002, pp. 578-580. In German doctrine, disserting about the interplay between human dignity and overall fairness in criminal procedure law, Roxin, Claus/SchünEMANN, BERND, Strafverfahrenrecht - Ein Studienbuch, 29. Auflage. München: C.H. Beck, 2017, passim.

71 A selection of SPP of a set of Guiding Cases in Chinese can be found in: https://www.chinalawtranslate.com/en/spp-guiding-cases/ (access: 23.08.2021).

72 Rawls, John, Justice as Fairness: A Restatement, 2nd edition (16th of May of 2001). Cambridge, Massachusetts: Belknap Press: An Imprint of Harvard University Press, 2001/2018, pp. 1-240 (noting that justice as fairness requires both a fair distribution of liberties and opportunities). No surprise springs from the fact that Rawls 'concept of fairness has flatly failed to capture the hideous social reality in both cultures of honour (mostly in Africa and Central and South America) and cultures of face (mostly in Southeast Asia and beyond), in which social inequalities and social imbalances not only abound but are appallingly rife. In a such a turbid and lopsided social reality, there is a yawning gap between rich and poor. As a result, there is no such thing as a fair distribution of liberties and opportunities worth mentioning 
Guiding Case 27 is amenable to be applied to, and is suitably tailored to, any criminal prosecution ${ }^{73}$. Corporate criminal liability, which forms part of a broader punitive apparatus, stands as no exception.

It is my firm conviction that SPP Guiding Case 27, being one of the linchpins of a sought-after clean, seamless and fair criminal proceeding, can contribute exponentially to fizzle out (and thereby drastically curtail) the both dispiriting and jarring rates concerning wrongful convictions in People's Republic of China.

SPP Guiding Case 27, if nothing else, can create a powerful deterrence effect ${ }^{74}$ on unprincipled prosecutors whom seek to unlawfully balloon their criminal convictions rates with hardly any regard for its underlying fairness. Which clearly runs in non-conformity with one of the primary drivers of, and propelling forces of, SPP Guiding Cases in the first place: yield procedural fairness to China's corporate criminal procedure law.

For that reason, unsanctioned detours (mirrored on the lack of procedural fairness evinced by those whom were allotted with the task to navigate through the uncharted waters of due process - criminal prosecutors) deserve nothing but to be severely excoriated and upbraided accordingly. Should such flagitious behaviours be perpetrated by the

to begin with. Additional remarks on this sweltering issue extend far beyond the limited spectrum of this paper though.

73 Hawes, Colin, "Transforming the Culture of Chinese Prosecutors Through Guiding Cases”, cit.

74 Cardi, Jonathan/Penfield, Randall D./Yoon, Albert H., Does Tort Law Deter Individuals? A Behavioral Science Study, Journal of Empirical Legal Studies, vol. 9, n. ${ }^{\circ}$ 3, 2012, pp. 567-603 (the authors stressed, however, premised on a sound empirical evidence, that "the threat of potential criminal sanctions had a large and statistically significant effect on subjects 'stated willingness to engage in risky behaviour"). Deterrence often crisscross paths with an yearned (and yet poorly latched on) legitimacy model, which can prop up the overall effectiveness of a given system of administration of criminal justice by putting in place incentives to spur prosecutors 'voluntary compliance with the nub of SPP's Guiding Cases. See: Tyler, Tom, Methodology in Legal Research, Utrecht Law Review, vol. 13, n. ${ }^{\circ} 3$, 2017, pp. 131-133 (argues that the "legitimacy-based model is distinct in two ways. First, it offers an alternative perspective on why people obey the law. Second, it suggests an alternative goal to compliance. That goal is voluntary and willing acceptance. Hence, this is a consensual model" (italics added). 
prosecutors, they must neither go unnoticed nor unchecked ${ }^{75}$ (let alone unpunished ${ }^{76}$ ) if China's system of administration of justice is to meet the baseline standards of an internationally-recognized due process.

With this context in place, SPP Guiding Cases fits, hand-inglove, to the discourse of procedural fairness and procedure fairness. Due process, which has been enduring a withering series of worldwide attacks to its core, does not fall far behind. Due process, which is a place to dwell permanently, must be attuned with the relentless combat against procedural unlawfulness in China's corporate criminal procedural law accordingly.

If the battle against unlawfulness wages on, so too does the dream of procedural fairness, which is bound to (hopefully) find a footprint in reality as China's criminal system of justice keeps attracting a wide global gaze ${ }^{77}$.

The overall fairness of China's criminal system of justice, which has experienced sizable roadblocks in the past ${ }^{78}$, must not be bedraggled with the indelible stain of unlawfulness, which would not only dampen (worse yet: would put in jeopardy) its laudable undertaking in building a clean, fair, fuss-free and unencumbered criminal system of justice, but, and foremost, would snuff out corporations' yearning hope to be

75 Blum, W. J./Kalven, H., "The Empty Cabinet of Dr. Calabresi - Auto Accidents and General Deterrence", University of Chicago Law Review, 34, 1967, pp. $268 \mathrm{ff}$ (averring that law also pursues the goal of, and resonates with, allaying victim's feeling of utter indignation).

76 Green, Michael D., Comparative Stimulations for Developing Tort Law, Koziol, Helmut (ed.), European Centre of Tort Law and Insurance Law. Wien, Austria: Jan Sramek Verlag, 2016, p. 35 (argues that "one who has harmed by the wrongdoing of another might justifiably appeal to fairness in righting a wrong as the basis for demanding recompense from the wrongdoer") (italics added). See also: Calabresi, Guido, The Costs of Accidents: A Legal and Economic Analysis. New Haven: Yale University Press, 1970/2019, pp. 1-350 (passim) (argues that one of the overriding goals of tort law is afford to plaintiff's justice, fairness, and redress from wrongs).

77 See: https://www.peacedirect.org/what-we-do/justice-human-rights/?gclid=CjwKCAjw95yJBhAgEiwAmRrutPpn7FentItKkSgdjKdKzaKKdceE1nj0HcVwAxvCMRtzI46iAjIJRoCtL4QAvD_BwE (access: 26.08.2021).

78 McConville, Mike (ed.), Criminal Justice in China: An Empirical Inquiry. Cheltenham, UK: Edward Elgar, 2011. 
bestowed upon procedural fairness that abhors prosecutorial misconduct in corporate criminal procedure law.

As it stands, China's criminal system of justice is to bode well in the forthcoming future as purports, as hinted above, to scrub out any shiver of illegality while toiling towards the overriding goal to ascribe perceptions of procedural fairness upon corporations (or individual defendants) that find themselves trapped into the labyrinthic corridors of criminal procedure law. The assertion according to which China's criminal system of justice is currently gathering pace (and therefore gaining traction) as to tune itself into the universal energies of fairness is neither unwarranted nor uncalled for.

In a bid to chime in with the universal energies of, and thereby impregnated by the spirit of, procedural fairness, which is rooted firmly in the Rule of Law, SPP Guiding Cases spearheaded a drastic overhaul (which is often coined as a paradigm shift ${ }^{79}$ ) in China's criminal system, which stretched from the outset of the previous decade to its twilight.

SPP Guiding Cases thus sought to jettison both unlawfulness and prosecutor misconduct (which is often the by-product of police misconduct ${ }^{80}$ ) in criminal procedure law into deep space. SPP Guiding Cases therefore stood at the forefront of a staggering effort to throw both procedural unfairness and procedural injustice out of balance.

Whilst the underlying narrative of paradigm shifts often differ by the teller ${ }^{81}$, SPP Guiding Cases have arguably shone a keen light on the dire need to usher in procedural fairness in People's Republic of China

79 Hawes, Colin, Transforming the Culture of Chinese Prosecutors Through Guiding Cases, cit.

80 Bains, Chiraag, A Few Bad Apples: How the Narrative of Isolated Misconduct Distorts Civil Rights Doctrine, Indiana Law Journal, 93, 2018, pp. 29 and ff (argues that police misconduct undermines, taints and sullies constitutional protections afforded to defendants in criminal procedure law).

${ }^{81}$ A distinct legacy of legal pragmatism, whose fundamental tenets are not amenable to be fleshed out in this paper given its utterly limited scope. See on the surrounding rhetoric underpinning paradigm shifts in People's Republic of China, in French language: Xiao-Ying-Li-Kotovtchickhine, Pragmatisme juridique et role de la Constituition en Chine post-Mao, Revue Internationale de droit comparé, 2018, 3, 2018, pp. 446 ff and passim. 
criminal procedure law as the former encapsulates an invaluable tool to create a brand-new prosecutorial culture from scratch.

Against this background, SPP Guiding Cases catalyzed a muchneed change not only in (a previously shoddy and watered-down) prosecutorial culture, which paid scarce attention to procedural fairness, but, and foremost, paved the way to ground-breaking legislative changes in People's Republic of China criminal procedural law.

Amongst other momentous legislative changes (like the Administrative Punishment Law of People's Republic of China ${ }^{82}$ reshuffled in 2021, which will be briefly parsed further down this paper), there were comprehensive and sweeping revisions on People's Republic of China Criminal Procedure in $2012^{83}$ and on People's Republic of China Procurators Law in $2019^{84}$ catalyzed by SPP Guiding Cases of 2010. From which several fairness-fraught corollaries can be withdrawn accordingly, as follows.

\section{Fairness-fraught corollaries that CAN be WithdraWn From

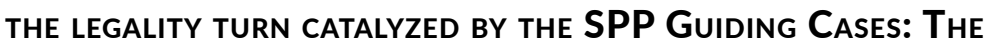 RIGHT TO A FAIR TRIAL AND THE RIGHT TO AN EFFECTIVE DEFENCE SHOULD BE ALLOTTED TO CORPORATIONS}

The right to a fair trial and the right to an effective defence in criminal proceedings lie at the heart of the fairness-fraught Criminal Procedure Law of China (art. ${ }^{\circ} 11 .^{\circ}$, $^{\text {art. }}{ }^{\circ} 12 .^{\circ}$ and art. $^{\circ} 14 .^{\circ}$ ). Which derives, as hinted above, from the legality turn set in motion by the SPP Guiding Cases that harkens back to 2010. Corporate criminal procedure law must stand as no exception.

In this respect, there is an agreed-upon consensus that both the right to a fair trial and the right to an effective defence in criminal law

82 http://www.npc.gov.cn/englishnpc/c23934/202105/f18b60e2b2ed4198ab12fa3ac999fc5a.shtml (access: 27.08.2021).

83 http://www.npc.gov.cn/zgrdw/englishnpc/Special_11_5/2012-01/19/ content_1691154.htm (access: 26.08.2021).

84 http://www.npc.gov.cn/englishnpc/c23934/202012/8b5601506cde4341b1d24ae2bfd195ee.shtml (access: 26.08.2021). 
settings comprise ${ }^{85}:$ i) the right to remain silent; ii) the impossibility of convicting a defendant based solely upon his confession in the absence of other smoking-gun evidence (art. ${ }^{\circ} 55 .^{\circ}$ of Criminal Procedure Law of China) iii) the right to be represented by an attorney at law or an lawyer in criminal proceedings ${ }^{86}\left(\right.$ art. $^{\circ} 14 .^{\circ}$, and art. $^{0} 190 .{ }^{\circ}$ of Criminal Procedure Law of China); iv) impossibility to extort confessions by torture and to collect evidence as a result of threat, enticement, deceit or other unlawful inflicted upon the defendant (被) in criminal law settings ${ }^{87}$ (art. ${ }^{\circ} 56 .^{\circ}$ of Criminal Procedure Law of China).

The judicial interpretations ${ }^{88}$ issued by the Supreme Court of People's Republic of China (中華人民共和國最高法院頒布的司法解釋) ${ }^{89}$

85 See: Liu, Sida/ Halliday, Terrence C., Criminal Defense in China: The Politics of Lawyers at Work. Cambridge: Cambridge University Press, 2016 passim (on the right to a fair trial and the pivotal role that lawyers play in attaining such an encomiastic goal).

86 But see: Fu, Hualing, The July $9^{\text {th }}$ (709) Crackdown on Human Rights Lawyers: Legal Advocacy in an Authoritarian State, Journal of Contemporary China, 27, 2018, pp. 555-567 (on the challenges that criminal lawyers have been facing in China).

87 Minzner, Carl F., The Rise and Fall of Chinese Legal Education, Fordham International Law Journal, 36, 2013, pp. 334-395 (which, on its face, accounts for the augmentation of legal education in China).

On the pivotal role played by judicial interpretation in several jurisdictions: Samuel, Geoffrey, All that Heaven Allows: Are Transnational Codes a "Scientific Truth" or Are They Just a Form of Elegant "Pastiche, Methods of Comparative Law, Research Handbooks in Comparative Law Series, Pier Giuseppe Monateri (ed.). Cheltenham United Kingdom: Edward Elgar Publishing, 2012, pp. 165-170 ("Methods of Comparative Law brings to bear new thinking on topics including: the mutual relationship between space and law; the plot that structures legal narratives, identities and judicial interpretations; a strategic approach to legal decision making; and the inner potentialities of the 'comparative law and economics' approach to the field") (italics added) (emphasizing the paramount importance of judicial interpretations in comparative law).

89 See: Judicial Interpretation enacted by the Supreme Court of People's Republic of China n. ${ }^{\circ}$ 17/1999 (on the "Supreme Court interpretation on the specific issues related to the application of criminal law in hearing criminal cases involving crimes committed by a Unit"). See also: Judicial Interpretation enacted by the Supreme Court of People's Republic of China n. ${ }^{\circ}$ 31/2000 ("Supreme Court interpretation on the question of whether or not, in hearing the cases of crimes committed by a unit, should distinguish principal 
encapsulate a penchant for extending the set of criminal procedural law guarantees ascribed to natural persons (such as the right to a fair trial and, foremost, the right to an effective defence in criminal proceedings) to Units or corporations. Such a stance resonates with one of the keystones of China's "Socialist Rule of Law" ${ }^{\text {, }}$ which deserves nothing but a spate of unfettered plaudits.

Against this background, the extension of the principle of nemo tenetur se ipsum accusare to both Units and Organizations does neither seems unwarranted nor uncalled for ${ }^{91}$. Which, if endorsed by the higher

criminal or the accomplice between the persons who are directly in charge and the other persons who are directly responsible for the crime"). Which begs the question: what consist of judicial interpretations in the remit of China's Criminal Procedure Law? What do they stand for? It has been said that "Judicial interpretations by the Supreme People's Court (SPC) play an important role in the Chinese legal system, as they provide often-detailed guidance to courts throughout the country about how to interpret existing laws. Written in response to a perceived need rather than to resolve a single case, judicial interpretations function almost as laws or regulations, filling gaps and answering questions". See: https://www.faegredrinker.com/en/insights/publications/2009/6/interpretations-of-the-supreme-peoples-court-on-certain-issues-concerning-the-application-of-the-con (access: 18.03.2021). See: Zhang, Yingjun, Corporate Criminal Responsibility in China: Legislations and its Deficiency, Beijing Law Review, 3, 2012, pp. $103 \mathrm{ff}$ and passim, whose research I have followed very closely; Yang, Vincent Cheng, Corporate Crime: Stateowned Enterprises in China, in: Criminal Law Forum, 6, 1995, pp. 143-165; Zhenjie, Zhou, Corporate Crime in China: History and Contemporary Debates. New York: Routledge, 2015, pp. 1-204 (passim); Lin, Lin, Corporate Crime in China: History and Contemporary Debates by Zhou Zhenjie, Singapore Journal of Legal Studies, 1, 2015, pp. 285 ff. Whose stellar research served as lodestar (and reference) in this regard.

90 See: Chinese Common Law Guiding Cases, Harvard Law Review, 129, 2016, p. 2213 (in this vein, there have been a set of calls to take heed of the pinpointed cultural and legal differences by, in the case of People's Republic of China, allow for a "Socialist Rule of Law"). See: Limmer, Jocelyn E. H., China's New "Common Law": Using China's Guiding Cases to Understand How to do Business in the People's Republic of China, Willamette Journal of International Law and Dispute Resolution, 21, 2013), pp. 96-113 (argues that, with the creation of guiding cases, China is gearing towards the "recognition of Chinese legal precedent").

${ }^{91}$ See in German doctrine: Queck, Nadine, Die Geltung des nemo-tenetur-Grundsatzes Die Geltung des nemo-tenetur-Grundsatzes zugunsten von Unternehmen. Berlin: Duncker and Humblot, 2005, pp. 204-231; Eidam, Lutz, Die strafprozessuale Selbstbelastungsfreihei am Beginn des 21. Jahrhunderts, Frankfurt am 
echelons of the Chinese judiciary, is amenable to yield a number of reputational benefits (amongst which stands trust ${ }^{92}$ and trustworthiness ${ }^{93}$ ) to (on) the (often misunderstood and poorly latched on) Criminal Procedure Law of China.

\subsection{Corporate Compliance PRograms amount to DefENCES to EXCLUDE OR MITIGATE THE UNIT'S OR ORGANIZATION'S CORPORATE CRIMINAL LIABILITY}

The dire need of effective compliance programs is a social reality that is not to be bogged down to the United States of America ${ }^{94}$. Which, considering what has been said earlier in this paper, hardly amounts to a bewildering statement. As stated in Part I of this paper, there is no such thing as an ethical corporate citizen devoid of, and detached from, brawny foundations of an ethical-fraught and law-abiding corporate governance ${ }^{95}$.

Main, Peter Lang, 2007), pp. 8-58 (arguing that the principle of nemo tenetur se ipsum accusare should be extended to corporations in the remit of corporate criminal liability).

See: Tyler, Tom R., Trust in the Law, New York, NY: Russell-Sage,2002, passim (on the crucially important role of trust in law and trust in the law).

See: Welsh, Nancy A., The Reputational Advantages of Demonstrating Trustworthiness: Using the Reputation Index with Law Students, Negotiation Journal, 28, 2012, pp. 118-135 (on the interplay between enhanced trust and perceptions of justice, which are to give rise to reputational advantages of demonstrating trustworthiness in dispute resolution settings).

See: Soltes, Eugene, Evaluating the Effectiveness of Corporate Compliance Programs: Establishing a Model for Prosecutors, Courts and Firms, New York University Journal of Law and Business, 14, 3, 2018, pp. 965-1012 (966) (argues that "over the past 25 years, the size and complexity of corporate compliance programs have increased dramatically. As budgets for supporting programs and the number of people involved with compliance processes have grown, compliance has transformed into its own division within many firms").

Effective (and functional) corporate compliance programs matter. Indeed. And an ethical-fraught corporate governance lies at its heart. See: Hess, David, Ethical Infrastructures and Evidence-Based Corporate Compliance and Ethics Programs: Policy Implications from the Empirical Evidence, New York University Journal of Law and Business, 12, 2016, pp. 316 ff (one must not lose sight of the fact that the inception of the corporate compliance programs is to be traced back to the 1970's and 1980's amidst the notorious corruption scandals that included several firms defrauding the United States of America Government). 
They do not collide. Rather, they (must) dovetail seamlessly. Better yet: the lack of an effective corporate governance ${ }^{96}$ (and hence the lack of an effective corporate compliance program ${ }^{97}$ ) paves the way to corporate criminal liability ${ }^{98}$.

Though no reference whatsoever to corporate compliance programs is made in the remit of both corporate criminal procedure law of China and criminal law of China, the same cannot be said in regards of other paramount branches of law. The wide-scope reforms undertaken in Administrative Punishment Law in 2021, albeit seemingly unrelated with criminal procedure law, play a pivotal role in gauging the degree to which a Unit or an Organization is a law-abiding company entitled to be afforded social credits on the grounds of an ethical corporate governance. Companies are thus urged to toil towards the goal of clutching the holygrail of social credits, which is to streamline their business activities in China; in that companies are nudged ${ }^{99}$ towards both law-abidingness ${ }^{100}$

96 Lack of which often amounts to a corporate compliance program wrapped in tokenism. In other words: equates to cosmetic compliance bereft of any effectiveness whatsoever. See: Krawiec, Kimberly D., Cosmetic Compliance and the Failure of Negotiated Governance, Washington University Law Review, 81, 2003, pp. $486 \mathrm{ff}$ (on the sizzling hot topic of cosmetic compliance against the backdrop of the so-called failure of negotiated governance).

97 See: Baer, Mariam, Governing Compliance, Boston College Law Review, 50, 2009, pp. 1-24 (passim) (argues that there must be an institution (like the DOJ - Department of Justice) to gauge the extent to which, and to declare whether and to what extent, "compliance programs" are "effective or deficient").

98 Arlen, Jennifer, The Failure of the Organization Sentencing Guidelines, University of Miami Law Review, 66, 2012, pp. $321 \mathrm{ff}$ (on the dire need to pin down misconduct in a bid to avoid corporate criminal liability).

99 Sunstein, Cass R., "The Ethics of Nudging”, Yale Journal on Regulation, cit.,: 415 (posits that "both nudges and choice architecture are inevitable, and it is therefore pointless to wish them away"). See also: Thaler, Richard H./Sunstein, Cass R., Nudge: Improving decisions about health, wealth, and happiness. London: Penguin Books, 2009 (on the myriad of benefits of nudging to improve welfare and to strive for better choices).

100 Tyler, Tom R., Trust and Law Abidingness: A Proactive Model of Social Regulation, Boston University Law Review, 81, 2001, pp. 359 ff (on the cardinal importance of Law Abidingness). 
and ethical corporate citizenship ${ }^{101}$ underpinning a sought-after ethical corporate culture ${ }^{102}$.

To cater to that, People's Republic of China Administrative Punishment Law offers a wide range of social credits out of the meaningful corporate compliance efforts undertaken by both the Units and the Organizations. The foregoing body of legislation, albeit placed at the outskirts of both criminal law and criminal procedure law, which has been approved on January 22, 2021 at the $25^{\text {th }}$ Session of the Standing Committee of the $13^{\text {th }}$ National People's Congress, has introduced a vast assortment of amendments to the archaic Administrative Punishment Law of the People's Republic of China of $1996^{103}$. Such an earth-shattering body of legislation has entry into force on July 15, $2021^{104}$.

Amongst several important legal provisions enshrined in People's Republic of China Administrative Punishment Law, there is one ( $\operatorname{art}^{\circ}{ }^{\circ} 33 .^{\circ}$ ) that stands out given its cardinal role in smoothing out the punishment (to be) inflicted upon the Unit or the Organization. Such legal provision governs the situation in which the flagitious behaviour is minor and staggering efforts have been made by the corporation to prevent the infliction of a harm unto others. Such a leniency measure stands as a byproduct of an effective (and functional) corporate compliance program that deserves nothing but undeterred praise.

${ }^{101}$ Carroll, Archie B., The Pyramid of Corporate Social Responsibility: Toward the Moral Management of Organizational Stakeholders, Business Horizons, (July-Aug. 1991), 1991, pp. 39-43 (on the paramount importance of corporate social responsibility).

${ }^{102}$ Davidon, Robert/Dey,Aiesha/Smith, Abbie, "Executives, Off-the-Job” Behaviour, Corporate Culture, and Financial Reporting Risk, Journal of Financial Economy, 117, 2015 pp. $4 \mathrm{ff}$ and passim (mapping out the fundamental tenets of an ethics-borne corporate culture).

${ }^{103}$ Available at: http://www.lehmanlaw.com/resource-centre/laws-and-regulations/administration/administrative-punishment-law-of-the-peoples-republic-of-china-1996.html (access: 18.03.2021).

${ }^{104}$ Available at: http://www.compliancereviews.cn/Arc-v.Asp?ID=1052 (access: 18.03 .2021$)$. 


\subsection{FAIRNESS-FRAUGHT COROLLARIES THAT CAN BE WITHDRAWN FROM SPP \\ GUIDING CASES FROM A PROSPECTIVE POINT OF VIEW: WILL NEGOTIATED AGREEMENTS HOLD (ANY) SWAY ON THE CORPORATE CRIMINAL PROCEDURE LAW OF THE FUTURE?}

Although both Units and Organizations are being consistently urged to both design of effective compliance programs ${ }^{105}$ and to adopt $t^{106}$ an ethical ${ }^{107}$ corporate $^{108}$ behaviour ${ }^{109}$, there is no functional equivalent

105 See: Haugh, Tom, Cadillac Compliance" Breakdown, Stanford Law Review Online, 69 2017, pp. 198-204 (this author stands for a cadre of behavioural nudging to induce corporate compliance within organizational settings).

106 The adoption of effective corporate compliance programs begs for a socially integrated response to tackle the scourge of agency problem. Amongst which stands the sizzling hot topic of reverse agency problem, which amounts to a willingness evinced by companies to sacrifice their own directors at the altar of the companies 'best interests. This issue is often regarded as a by-product of the so-called era of compliance. Yet, however intriguing, such issue falls outside the scope of the paper. See on agency problem: Armour, John Armour/ Hansmann, Henry/ Kraakman,Reinier, Agency Problems, Legal Studies and Enforcement, Oxford University Faculty of Law Research Paper, n. ${ }^{\circ}$ 21/2009. Oxford: Oxford University Press, 2009, pp. 3 ff; Goshen, Zohar /Squire, Richard, Principal Costs: A New Theory for Corporate Law and Governance, Columbia Law Review, 117, 2017, pp. 766 ff;. On reverse agency problem:Eckstein, Asaf/Gideon Parchomovsky, Gideon, The Reverse Agency Problem in the Age of Compliance, University of Pennsylvania Carey Law School, Faculty Scholarship at Penn Law,2019 pp. 3-49.

107 Treviño, Linda Klebe/Nieuwenboer, Niki A. Den,/Kish-Gephart, Jennifer J., (Un)Ethical Behavior in Organizations, Annual Review of Psychology, 65, 2014, pp. 635 ff (on the multitudinous benefits of a corporate ethical behaviour against the backdrop of a host of psychological foundations that stand upon it).

108 See also: Soltes, Eugene, Why They Do It: Inside the Mind of the White-Collar Criminal. New York: Public Affairs, 2016, pp. 1-464 (48-62) (on the bevy of social science theories underpinning the proneness to engage in white-collar crime).

109 See: Shu, Linda Shu et al./Mazar, N./Gino, F./ Ariely, D./Bazerman, M. Signing at the Beginning Makes Ethics Salient and Decreases Dishonest Self-reports in Comparison to Signing at the End, Proceedings of the National Academy of Sciences, 109, 38, 2012, pp. 15197-15200 (on the dire need to ferret out pathways to prompt honest and ethical corporate behaviour. For example, asking the relevant stakeholders to sign documents at the very beginning rather than at the very end of the document). 
of United States of America's Department of Justice (DOJ) ${ }^{110}$ memos $^{111}$ in China to grant the enforcement of such legal directives in the purview of corporate criminal procedure law. Which, in my view, comes to the expense of, and is ultimately detrimental to, the effectiveness of corporate compliance programs in the purview of corporate criminal procedure law in China.

Though People's Republic of China has recently approved and released a Guidance on Compliance Management for Central Stated-Owned Enterprises $^{112}$ (chiefly targeting foreign multinational corporations that aim to do business with wholly State-owned companies headquartered in

${ }^{110}$ As hinted above, the Guiding Cases issued by the China's Supreme People's Procuratorate since 2010 have been playing a starring role in catering for the enhancement of substantive protection of criminal suspects. See: Colin Hawes, "Transforming the Culture of Chinese Prosecutors Through Guiding Cases", cit., 196 (argues that "fifteen sets of Guiding Cases issues by the Supreme People's Procuratorate since 2010 promote an unprecedented change in Chinese procurator culture away from "striking hard" to substantive protection of criminal suspects "rights and exclusion of tainted evidence. They reinforce criminal procedure reforms since 2010 by demonstrating how procurators should protect innocent people against wrongful convictions and police brutality").

111 The memos issued by the Office of the Deputy Attorney General, which have managed to describe the goals underpinning the corporate compliance programs, form part of a broader legal apparatus sedimented in the "Principles of Federal Prosecutions of Business Organizations”. See, amongst many other memos: Memorandum from Larry Thompson, Deputy Attorney General to Heads of Department Components, U.S. Attorneys (Jan. 20, 2003); Memorandum from Mark Filip, Deputy Attorney General to Heads of Department Components, U.S. Attorneys (Aug. 28, 2008). Available at: https://www.justice.gov/archives/dag/file/769036/download (access: 27.08.2021).

112 See: https://www.lw.com/thoughtLeadership/China-SASAC-Guidance-Com pliance-Management-Central-SOEs (access: 20.03.2021). ("The Guidance sets out four general principles for how Central Enterprises should establish and improve their compliance management systems, including: 1. Ensuring compliance management systems cover all business areas, departments, subsidiaries, branches, and personnel, as well as all decision, execution, and supervision procedures. 2. Strengthening the accountability of compliance personnel for implementing effective compliance management systems. 3 . Achieving cohesive cooperation and collaboration between the compliance function and other functions, such as legal, risk management, auditing, and internal controls. 4. Carrying out compliance responsibilities independently and objectively"). 
China), such a body of legal directives hardly has enough momentum to stand on its own as a full-fledged mechanism amenable to soothe out the punishment (if any) inflicted upon Central Stated-Owned Enterprises. Overall, such a manual of good practices, however redolent with ambrosial intentions, amounts to soft law ${ }^{113}$ with scarce to none binding effect on corporations.

To the extent that the cooperation between companies and the government must be both fruit-bearing and amenable to instill a deterrence effect ${ }^{114}$ upon wrongdoers, the future legal framework concerning negotiated agreements in China must, to some extent, emulate, mutatis mutandis, the ground-breaking Yates $\mathrm{Memo}^{115}$. Against the background of which the cooperation ${ }^{116}$ between Units and Organizations with the Chinese Public Prosecution Office would be a mitigating factor ${ }^{117}$ to the

${ }^{113}$ See, on soft law, albeit in a legal field wholly unrelated with corporate criminal liability, Canaris, Claus Wilhelm, Die Stellung der "UNIDROIT Principles" und der "Principles of European Contract Law" im System der Rechtsquellen, Europäische Vetragsrechtvereinheitlichung und deutsches Recht. Tübingen: Mohr Siebeck, 2000, pp. 5 ff.

${ }^{114}$ But see: Ma, Jingyuan/ Marquis, Mel, "Corporate Culture and Competition Compliance in East Asia”, South Carolina Journal of International Law and Business, 15, n. ${ }^{\circ}$ 1), Fall 2018, 2018, pp. 1-98 (6) (contend, however, that "research also shows that severe sanctions alone are unlikely to achieve deterrence and optimal compliance. An effective motivation to comply with the law is better secured by increasing the perceived value of such compliance and increasing the perceived risk that misconduct will be detected").

115 See: Memorandum from Sally Quillian Yates, Deputy Attorney General, U.S. Department of Justice, to all U.S. Attorneys et al., Individual Accountability for Corporate Wrongdoing (Sept. 9, 2015) (contends avowedly that "in order to qualify for any cooperation credit, corporations must provide to the Department all relevant facts relating to the individuals responsible for misconduct"), available at: https://www.justice.gov/archives/dag/file/769036/ download (access: 20.03.2021).

116 See: Department of Justice, Principles of Federal Prosecution of Business Organizations, U.S. Attorneys 'Manual (USAM) 9-28.700 - The Value of Cooperation (states that «cooperation is a mitigating factor, by which a corporation - just like any other subject of criminal investigation - can gain credit in a case that otherwise is appropriate for indictment and prosecution»), available at: https://www.justice.gov/jm/jm-9-28000-principles-federal-prosecution-business-organizations (access: 20.03.2021).

117 The tagged mitigation factor springs originally from the United States of America Organizational Guidelines, which has gathered (further) pace with 
former. The mitigation factor stands as an intellectual lodestar of the corporate criminal procedure law framework of several jurisdictions such as Spain ${ }^{118}$, Italy ${ }^{119}$ and France ${ }^{120}$ to name a few. Jurisdictions from which People's Republic of China could seek inspiration.

\section{Concluding Remarks}

$\S \S$ The relationship between a law-abiding corporate governance and a to-be-avoided corporate criminal liability has shown to be reciprocal.

$\S \S$ To avoid falling into the trap of corporate criminal liability, Chinese Units and Organizations must embrace a law-abiding corporate governance, whose paramount importance has been laid bare by remarkably sad events.

its revision in 2004. See: Laufer, William S., Corporate Bodies and Guilty Minds. Chicago/London: The University of Chicago Press, 2006), pp. $7 \mathrm{ff}$ and passim (providing an historical overview on corporate criminal liability). See also: O’Sullivan, Julie, “Some Thoughts on Proposed Revisions to the Organizational Guidelines”, Ohio State Journal of Criminal Law, (2004): pp. $488 \mathrm{ff}$ and passim (arguing, and rightly so, that the United States of America Organizational Guidelines afford a sentence credit to those companies which have designed an effective corporate compliance program).

118 The mitigating factor is to be warranted to companies that have either cooperated with the authorities or have implemented effective compliance programs prior the misconduct (art. ${ }^{\circ} 31$ quarter of Spanish Criminal Code). See in Spanish doctrine: Barranco, Mata/Gómez-Aller, Jacobo Dopico/Sánchez, Juan Antonio Lascuraín /Martín, Ádan Nieto, Derecho Penal Económico y de la Empresa. Madrid: Editorial Dykinson, 2018 pp. 157 ff.

${ }^{119}$ See in Italian doctrine: Ruggiero, Rosa Ana, Scelte Discrezionali del Publico Ministero e Ruolo Dei Modelli Organizzativi Nell'Azione Contro Gli Enti. Torino: G. Giapichelli Editore,2018 pp. 94-95 (on cooperation as a condition sine qua non to smoothe out out the corporate criminal liability of a given corporation).

${ }^{120}$ See in French doctrine: Juliette Lelieur, La Transaction judiciaire, les personnes morales et le droit des affaires”, Aktuelle und grundsätzliche Fragen des Wirtschaftsstrafrechts/Questions actuelles et fondamentales du droit penal. Berlin: Duncker \& Humblot, 2019), pp. 79-80 (arguing that Pretrial Diversion Agreements streamline the proceedings in the remit of corporate criminal liability given the fact that the procedure concerning this type of misdeeds is often cumbersome, unyielding, and slow, which further compounds the difficulty to prove such criminal charges in a court of law). 
$\S \S$ The design of effective corporate compliance programs draws on a robust, comprehensive and full-fledged law-abiding corporate governance, bereft (and absent) of which the former would be wrapped in tokenism thereby paving the way to corporate criminal liability.

$\S \S$ People's Republic of China prospective lawmakers and policymakers must be allotted the duty to enact legal provisions to govern the sizzling hot topic of the mitigation of corporate criminal liability pursuant an adoption of an effective corporate compliance program.

$\S \S$ Procedural fairness and procedure justice are crucially important as to carve out a seamless, fuss-free and fair criminal proceeding, which must rest upon the seemingly threadbare (yet of momentous importance in the remit of criminal procedure law) due process.

$\S \S$ SPP Guiding Cases (in conjunction with SPC judicial interpretations) catalyzed a seismic shift in China's criminal procedure law both from a perspective and prospective standpoint.

$\S \S$ SPP Guiding Cases resonate with a great leap forward when it comes to drastically stamping out a both botched and below-standard prosecutorial misconduct (which is often the by-product of police misconduct) that now belongs to the distant (yet murky) past.

$\S \S$ Hardly any surprise stems from the fact that SPP Guiding Cases were at forefront of a herculean effort to bestow upon criminal defendants (amongst which stand corporations) a much-needed procedural fairness and procedural justice, which are the foundations upon which stands due process: an interplay that prospective lawmakers must never lose sight of much less downplay.

\section{RefERENCES}

ALEXy, Robert, Theorie der Grundrechte. Frankfurt am Main: Suhrkamp, 1996.

Allison, J. W. F., Turning the Rule of Law into an English Constitutional Idea, May, C./Winchester, A. (Eds.), The Edward Elgar Handbook on the Rule of Law. Cheltenham, United Kingdom: Edward Elgar, 2018.

Andrade, Manuel da Costa, Nemo tenetur se ipsum accusare e direito tributário. Ou a insustentável indolência de um acórdão (n. ${ }^{\circ}$ 340/2013) do Tribunal 
Constitucional, Revista de Legislação e Jurisprudência, Ano $144 .^{\circ}$, novembro-dezembro de 2014, N. ${ }^{\circ}$ 3989. Coimbra: Coimbra Editora, 2015, pp. 144 e ss.

ArLEn, Jennifer, The Failure of the Organization Sentencing Guidelines, University of Miami Law Review, 66, 2012, pp. 321 ff.

Armour, John/Hansmann, Henry/Kraakman, Reinier, Agency Problems, Legal Studies and Enforcement, Oxford University Faculty of Law Research Paper, n. ${ }^{o}$ 21/2009. Oxford: Oxford University Press, 2009.

AzIz, Sarah F., Independence Without Accountability: The Judicial Paradox of Egypt's Failed Transition to Democracy, Penn State Law Review, 120, 2016, pp. 100 and $\mathrm{ff}$.

BAER, Mariam, Governing Compliance, Boston College Law Review, 50, 2009, pp. 1-24.

BAIns, Chiraag, "A Few Bad Apples": How the Narrative of Isolated Misconduct Distorts Civil Rights Doctrine, Indiana Law Journal, 93, 2018, pp. 29 and ff.

Bandes, Susan A., Video, Popular Culture, and Police Excessive Force: The Elusive Narrative of Over-Policing, University of Chicago Legal Forum, 2018, pp. 1-3.

Barranco, Mata/Gómez-Aller, Jacobo Dopico/Sánchez, Juan Antonio Lascuraín /Martín, Ádan Nieto, Derecho Penal Económico y de la Empresa. Madrid: Editorial Dykinson, 2018.

BAYEFsky, Rachel, Dignity as a value in Agency Cost-Benefit Analysis, Yale Law Journal, 123, 2014, pp. 1740 and ff.

Bibas, Stephanos, Transparency and Participation in Criminal Procedure, New York University Law Review, 81, 2006, pp. 911 ff.

Bird, Robert C./PARK, Stephen Kim, The Domains of Corporate Counsel in an Era of Compliance, American Business Law Journal, 53, 2016, pp. 203-229.

Blum, W. J./Kalven, H., "The Empty Cabinet of Dr. Calabresi - Auto Accidents and General Deterrence”, University of Chicago Law Review, 34, 1967, pp. 268 ff.

BRito, Teresa Quintela de, Domínio da organização para a execução do facto: responsabilidade penal de entes coletivos, dos seus dirigentes e "atuação em lugar de outrem”, Vols. I e II, Dissertação de doutoramento, Faculdade de Direito da Universidade de Lisboa, 2012.

Bussani, Mauro, Deglobalizing Rule of Law and Democracy: Hunting Down Rhetoric Through Comparative Law, The American Journal of Comparative Law, 67, 2019, pp. 701-744 (701). 
Byrne, Mari, Baseless Pleas: “A Mockery of Justice”, Fordham Law Review, 78, 2010, pp. 2961 and ff.

Calabresi, Guido, The Costs of Accidents: A Legal and Economic Analysis. New Haven: Yale University Press, 1970/2019.

CARDI, Jonathan/Penfield, Randall D./Yoon, Albert H., Does Tort Law Deter Individuals? A Behavioral Science Study, Journal of Empirical Legal Studies, vol. 9, n. ${ }^{\circ}$ 3, 2012, pp. 567-603.

CANARIS, Claus Wilhelm, Die Stellung der "UNIDROIT Principles" und der "Principles of European Contract Law” im System der Rechtsquellen, Europäische Vetragsrechtvereinheitlichung und deutsches Recht. Tübingen: Mohr Siebeck, 2000.

Carroll, Archie B., The Pyramid of Corporate Social Responsibility: Toward the Moral Management of Organizational Stakeholders, Business Horizons, (July-Aug. 1991), 1991, pp. 39-43.

Chan, Peter Chi Hin, The Enigma of Civil Justice in Imperial China, A Legal Historical Enquiry, Maastricht Journal of European and Comparative Law, 19, 2012, pp. 317-337.

Chan, Peter Chi Hin, The Position of Mediation in Contemporary Chinese Civil Justice: A Proceduralist Perspective, PhD dissertation in Civil Procedure Law, 2016.

Chan, Peter Chi Hin, Civil mediation in imperial, republican and modern-day China Historical and cultural norms under the traditional Chinese legal order, The Legal History Review, 85, 2017, pp. 577-602 (578).

Chen, Xingliang, Guiding Cases for China's Death Penalty, The Death Penalty in China: Policy, Practice, and Reform, Liang, Bin/Lu, Hong (Ed.). New York: Columbia University Press, 2015, pp. 187-213.

Chen, Jianfu, Criminal Law and Criminal Procedure Law in the People's Republic of China: Commentary and Legislation. Leiden: Martinus Nijhoff Publishers, 2016.

Chinese Common Law? Guiding Cases and Judicial Reform, Harvard Law Review, 129, 2016, p. 2234.

CoAtes, John C., Cost-Benefit Analysis of Financial Regulation: Case Studies and Implications, Yale Law Journal, 124, 2015, pp. 882-911.

Colomer, Juan-Luis Gómez (Dir.), Tratado sobre Compliance Penal. Responsabilidad penal de las personas jurídicas y modelos de organización y gestión. Valencia: Tirant lo Blanch, 2019. 
Colquitt, Jason A./Rodell, Jessica B., Justice, Trust, and Trustworthiness: A Longitudinal Analysis Integrating Three Theoretical Perspectives, Academy of Management Journal, 54, 2011, pp. 1183 ff.

Dias, Augusto Silva, O Direito Penal como instrumento de superação da crise económico-financeira: estado da discussão e novas perspectivas, Anatomia do Crime, Revista de Ciências Jurídico-Criminais, 0, 2014, pp. pp. 45-73.

DAvidon, Robert/Dey, Aiesha/Smith, Abbie, "Executives, Off-the-Job”, Behaviour, Corporate Culture, and Financial Reporting Risk, Journal of Financial Economy, 117,2015 , pp. 4 ff and passim.

Deng, Jinting, The Guiding Case System in China's Mainland, Frontiers of Law in China, 10, 2015, pp. 449 and ff.

Dworkin, Ronald, Law's Empire, Cambridge. Massachusetts: Belknap Press, 1986, 2016.

Eckstein, Asaf/Parchomovsky, Gideon, The Reverse Agency Problem in the Age of Compliance, University of Pennsylvania Carey Law School, Faculty Scholarship at Penn Law, 2019.

EIDAM, Lutz, Die strafprozessuale Selbstbelastungsfreihei am Beginn des 21. Jahrhunderts, Frankfurt am Main: Peter Lang, 2007.

EscARra, Jean, Le droit chinois. Paris: Dalloz, 1918.

FiERENS, Jacques, La dignitè humaine comme concept juridique, Journal des tribunaux, 121, 2002, pp. 578-580.

Finder, Susan, China's Evolving Case Law System in Practice, Tsinghua China Law Review, 9, 245, 2017, pp. 253 and ff.

FINNIS, John, Natural Law and Natural Rights, $2^{\text {nd }}$ edition. Oxford: Oxford University Press, 2011/2018.

Fu, Hialing, China's Striking Anticorruption Adventure: A Political Journey toward the Rule of Law?, The Beijing Consensus? How China Has Changed the Western Ideas of Law and Economic Development, CHEN, Weitseng (Editor). Cambridge: Cambridge University Press, 2017.

Fu, Hualing, The July $9^{\text {th }}$ (709) Crackdown on Human Rights Lawyers: Legal Advocacy in an Authoritarian State, Journal of Contemporary China, 27, 2018, pp. 555-567.

Goshen, Zohar /SQuire, Richard, Principal Costs: A New Theory for Corporate Law and Governance, Columbia Law Review, 117, 2017, pp. 766 ff. 
Global Pound Conference Global Trends Report from Herbert Smith Freehills and PwC, Global Pound Conference: Global Data Trends and Regional Differences Series, available at: https://www.pwc.com/gx/en/forensics/gpc-2018-pwc.pdf (access: 08.07.2021).

Green, Michael D., Comparative Stimulations for Developing Tort Law, KozIOL, Helmut (ed.), European Centre of Tort Law and Insurance Law. Wien, Austria: Jan Sramek Verlag, 2016.

Grotius, Hugo, Le droit de la guerre et de la paix, II, cap. XVII, I. Paris: Presses Universitáires de France, (1625: $1^{\text {st }}$ edition), (2 $2^{\text {nd }}$ edition of 2016), 2016.

Hassemer, Winfried, Symbolisches Strafrecht und Rechtsgüterschutz, NSTZ, München, 89, 2014, pp. $557 \mathrm{ff}$ and passim.

Haugh, Todd, Nudging Corporate Compliance, American Business Law Journal, 54, 2017a, pp. 683-705.

Haugh, Tom, Cadillac Compliance Breakdown, Stanford Law Review Online, 69, 2017b, pp. 198-204.

Hawes, Colin, Improving the Quality of the Judiciary in China: Recent Reforms to the Procedures for Appointing, Promoting \& Discharging Judges, Appointing Judges in an Age of Judicial Power: Critical Perspectives from Around the World, Malleson, K. E./Russell, Peter H. (Editors). Toronto: University of Toronto Press, 2016, pp. 395-419.

Hawes, Colin, How Chinese Judges Deal with Ambiguity in Corporate Law: Suggestions for improving the Chinese Case Precedent System, Australian Journal of Asian Law, 19, n. ${ }^{\circ}$ 1, 2018, pp. 1-22.

Hawes, Colin, Transforming the culture of Chinese Prosecutors through Guiding Cases, New Criminal Law Review, 23, n. ${ }^{\circ}$ 2, 2020, pp. 196-235.

Hess, David, Ethical Infrastructures and Evidence-Based Corporate Compliance and Ethics Programs: Policy Implications from the Empirical Evidence, New York University Journal of Law and Business, 12, 2016, pp. 316-320.

Holloway, David/Lin, Feng/Li, Linda Chelan/Zheng, Xiaohe/Kwok, Mantak, Strengthening Hong Kong's Position as an Arbitration Hub in the Belt and Road Initiative, International Arbitral Law Review, 21, 4, 2018, pp. 106-107.

Hussemann, Jeanette/Siegel, Jonah, Pleading Guilty: Indigent Defendant Perceptions of the Plea Process, Tennessee Journal of Law and Policy, 13, 2019.

Jiahong, He, Case Study on the Causes of Wrongful Conviction in Chinese Criminal Proceedings, Frontiers of Law in China, 10, 2015, pp. 671 and ff. 
Johnson, Thea, Public Perceptions of Plea Bargaining, American Journal of Criminal Law, 46, n. ${ }^{\circ} 1,2019$, pp. 133-156.

Jolls, Christine, Debiasing Through Law and the First Amendment, Stanford Law Review, 67, 2015, pp. 1411 ff.

Jolls, Christine/Sunstein, Cass R., Debiasing Through Law, John M. Olin Program in Law and Economics Working Paper n. ${ }^{\circ} 225,2004$, p. 1.

Justice, Department of, Principles of Federal Prosecution of Business Organizations, U.S. Attorneys 'Manual (USAM) 9-28.700 - The Value of Cooperation, available at: https://www.justice.gov/jm/jm-9-28000-principles-federal-prosecution-business-organizations (access: 20.03.2021).

KANT, Immanuel, Lectures and Drafts on Political Philosophy, Rauscher, Frederick/ Westphal, Kenneth R. (Editors). Cambridge: Cambridge University Press, 2016.

KaPlan, Jeffrey M., Compliance Programs and the Corporate Sentencing Guidelines, \& 6: 21. Westlaw: Thomson Reuters, 2021.

KASISKE, Die Selbstbelastungsfreiheit im Strafprozess, JuS, 2014, pp. 23-26.

Krawiec, Kimberly D., Cosmetic Compliance and the Failure of Negotiated Governance, Washington University Law Review, 81, 2003, pp. 486 ff.

LARkin, Paul J./SeIBler, John-Michael, All Stick and No Carrot: The Yates Memorandum and Corporate Criminal Liability, Stetson Law Review, 46, 2016, pp. 7-8.

LAufer, William S., Corporate Bodies and Guilty Minds. Chicago/London: The University of Chicago Press, 2006.

LEIBNIZ, Gottfried Wilhelm, Nova methodus discendae docendaeque jurisprudentiae (The New Method of Learning and Teaching Jurisprudence According to the Principles of the Didactic Art Premised on the General Part and in the Light of Experience: A Translation of the 1667 Frankfurt Edition with Notes by Carmelo Massimo de Iuliis. Ringwood, Hampshire, United Kingdom: Talbot Publishing, 2017.

LeLIEUR, Juliette, La Transaction judiciaire, les personnes morales et le droit des affaires, Aktuelle und grundsätzliche Fragen des Wirtschaftsstrafrechts/Questions actuelles et fondamentales du droit penal. Berlin: Duncker \& Humblot, 2019.

Limmer, Jocelyn E. H., China's New “Common Law”: Using China's Guiding Cases to Understand How to do Business in the People's Republic of China, Willamette Journal of International Law and Dispute Resolution, 21, 2013, pp. 96-113.

LiN, Lin, Corporate Crime in China: History and Contemporary Debates by Zhou Zhenjie, Singapore Journal of Legal Studies, 2015, pp. 285-287. 
Lin, Xifen/Shen, Wei, Reforms to China's pretrial detention system: the role of the procuratorate, International Journal of Law, Crime and Justice, 44, 2016, pp. 183-211.

Lino, Dylan, The Rule of Law and the Rule of Empire: A.V. Dicey in Imperial Context, The Modern Law Review, 81, 5, 2018, passim.

Liu, Sida/ Halliday, Terrence C., Criminal Defense in China: The Politics of Lawyers at Work. Cambridge: Cambridge University Press, 2016.

MA, Jingyuan/Marquis, Mel, Corporate Culture and Competition Compliance in East Asia, South Carolina Journal of International Law and Business, 15, n. ${ }^{\circ} 1$, Fall 2018, 2018, pp. 1-98 (6).

Magalhães, Pedro C. /Garoupa, Nuno, Judicial Performance and Trust in Legal Systems: Findings from a Decade of Surveys in 20 European Countries, Social Science Quarterly, 2020, pp. 1 and ff.

MARAsco, Gerardo, La rinegoziazione del contrato - strumenti legali e convenzionali a tutela dell'equilibrio negoziale. Padova: Cedam, 2006.

McConville, Mike (ed.), Criminal Justice in China: An Empirical Inquiry. Cheltenham, UK: Edward Elgar, 2011.

Minzner, Carl F., The Rise and Fall of Chinese Legal Education, Fordham International Law Journal, 36, 2013, pp. 334-395.

Miranda, Jorge, Os valores permanentes da Constituição portuguesa, Julgar, n. ${ }^{\circ}$ 29, maio-agosto 2016. Coimbra: Almedina, 2016, pp. 45-47.

Montesquieu, L'Espirit des Lois, Une édition électronique réalisée à partir du livre Montesquieu, De l'esprit des lois (1758). Édition établie par Laurent Versini, professeur à la Sorbonne. Paris: Éditions Gallimard, 1995, 2 vols: vol I: pp. 1 à 604; vol. II: pp. 605 à 1628.) Collection folio Essais, 1995.

Murphy, Diana E., The Federal Sentencing Guidelines for Organizations: A Decade of Promoting Compliance and Ethics, Iowa Law Review, 87, 2002, pp. 697-711.

NAUcke, Der Begriff der politischen Wirtschaftsstrafrecht - Eine Annährung, LIT, 2012, pp. 8-72.

NG, Michael H. K., Legal Transplantation in Early Twentieth-Century China. Abingdon-on-Thames: Routledge, 2016.

NovaIs, Jorge Reis, A dignidade da pessoa humana, Coimbra, Almedina, vol. II 2016.

O'Sullivan, Julie, Some Thoughts on Proposed Revisions to the Organizational Guidelines, Ohio State Journal of Criminal Law, 2004, pp. 488 ff. 
PeI, Minxin, China's Crony Capitalism: The Dynamics of Regime Decay. Cambridge: Massachusetts, Harvard University Press, 2016.

Posner, Eric A./Weyl, E. Glen, Cost-Benefit Analysis of Financial Regulations: Response to Criticisms, Yale Law Journal, 124, 2015, pp. 246-265.

Priester, Benjamin J., From Jones to Jones: Fifteen Years of Incoherence in the Constitutional Law of Sentencing Factfinding, University of Toledo Law Review, 47, 2016, pp. 413 and ff.

Prime, Penelope B., China Joins the WTO: How, Why, and What Now?, Business Economy, Business Economy, 37, 2002, pp. 26-32, available at: https://era.ong/ wp-content/uploads/china-joins-wto-1.pdf (access: 03.03.2021).

Queck, Nadine, Die Geltung des nemo-tenetur-Grundsatzes Die Geltung des nemo-tenetur-Grundsatzes zugunsten von Unternehmen. Berlin: Duncker and Humblot, 2005.

RAWLS, John, Justice as Fairness: A Restatement, 2nd edition (16th of May of 2001). Cambridge, Massachusetts: Belknap Press: An Imprint of Harvard University Press, 2001/2018.

RAwls, John, A Theory of Justice, $2^{\text {nd }}$ edition. Cambridge, Massachusetts: Belknap Press: An Imprint of Harvard University Press, 1999, 2019 (reprint).

RAz, Joseph, The Rule of Law and its Virtue, The Authority of Law: Essays on Law and Morality, Essays on Law and Morality. Oxford: Clarendon Press.

REILly, Peter, Negotiating Bribery: Toward Increased Transparency, Consistency, and Fairness in Pretrial Bargaining Under the Foreign Corrupt Practices Act, Hastings Business Law Journal, 10, 2014, pp. 347-378.

Rivas, Garcia, Reflexiones sobre la responsabilidad penal en el marco de la crisis financeira, Demetrio Crespo (Dir.), Crisis financera y Derecho Penal Económico, 2014.

Rousseau, Jean Jacques, Du Contrat Social, ou Principes du Droit Politique, Bibliothéque publique et universitaire de Geneve (première version). Publication, Amsterdam, février-mars 1762, REy, Marc Michel et al; le Pléiade édition t. III, pp. 347-470, 1866-1874. == Du Peyrou/Moultou 1780-1789 quart édition; t. I, 1782.

Roxin, Claus/Schünemann, Bernd, Strafverfahrenrecht - Ein Studienbuch, 29. Auflage. München: C.H. Beck, 2017.

Ruggiero, Rosa Ana, Scelte Discrezionali del Publico Ministero e Ruolo Dei Modelli Organizzativi Nell’ Azione Contro Gli Enti. Torino: G. Giapichelli Editore, 2018. 
SAmuel, Geoffrey, All that Heaven Allows: Are Transnational Codes a "Scientific Truth" or Are They Just a Form of Elegant "Pastiche, Methods of Comparative Law, Research Handbooks in Comparative Law Series, Pier Giuseppe Monateri (ed.). Cheltenham United Kingdom: Edward Elgar Publishing, 2012.

SÁNCHEz, Bernardo Feijoo, Sobre la «administrativizácion» del Derecho penal en la «sociedad de riesgo»: un apunte sobre la política criminal a princípios del diglo XXI, Derecho Y Justicia Penal en el Siglo XXI. Liber Amicorum en Homenaje al Profesor Antonio González-Cuéllar Garcia. Madrid: Ed. Colex, 2006.

SHAOWEI, Lin, The Empirical Studies of China's Enterprise Bankruptcy Law: Problems and Improvements, International Insolvency Review, 27, 2018, pp. 77-85.

SHIGA, S. A Study of Chinese Legal Culture Focusing on the Litigation Landscape, Journal of Comparative Law, 3, 1988, pp. 18-26 [滋贺秀三 “中國法文化的考察 以訴訟的形態為素材’ 1988年第3期《比较法研究》18-26].

Shiyuan, Huang, Chinese Wrongful Convictions: Causes and Prevention, University of Cincinnati Law Review, 80, 2012, pp. 1218 and ff.

Soltes, Eugene, Why They Do It: Inside the Mind of the White-Collar Criminal. New York: Public Affairs, 2016.

Soltes, Eugene, Evaluating the Effectiveness of Corporate Compliance Programs: Establishing a Model for Prosecutors, Courts and Firms, New York University Journal of Law and Business, 14, 3, 2018, pp. 965-1012.

Steele, Stacy et al., Trends and Developments in Chinese Insolvency Law: The First Decade of the PRC Enterprise Bankruptcy Law, in: The American Journal of Comparative Law, 66, 2018, pp. 669 e ss.

Shiyuan, Huang, Chinese Wrongful Convictions: Causes and Prevention, University of Cincinnati Law Review, 80, 2012, pp. 1219 and ff.

Shu, Linda Shu et al./Mazar, N./Gino, F./Ariely, D./Bazerman, M. Signing at the Beginning Makes Ethics Salient and Decreases Dishonest Self-reports in Comparison to Signing at the End, Proceedings of the National Academy of Sciences, 109, 38, 2012.

Sunstein, Cass R., The Real World of Cost-Benefits Analysis: Thirty-Six Questions (and almost as many answers), Columbia Law Review, 114, n. ${ }^{\circ}, 2014$, pp. 177 ff.

Sunstein, Cass R., The Ethics of Nudging, Yale Journal on Regulation, 32 (2/6), 2015.

Taekema, Sanne, The Procedural Rule of Law: Examining Waldron's Argument on Dignity and Agency, Jahrbuch für Recht und Ethik, Band 21, 2013, pp. 133 ff. 
Tippet, Elizabeth/Alexander, Charlotte S./Eigen, Zev J., When Timekeeping Software Undermines Compliance, Yale Journal of Law and Technology, 19, 2017, pp. 1 and ff.

Thaler, Richard H./Sunstein, Cass R., Nudge: Improving decisions about health, wealth, and happiness. London: Penguin Books, 2009.

Trevaskes, Susan, Courts and Criminal Justice in Contemporary China. Lanham, United States of America: Lexington Books, 2007.

Trevaskes, Susan, Death sentencing for stability and harmony, The Politics of Law and Stability in China. Cheltenham Glos, United Kingdom: Edward Elgar, 2015.

Treviño, Linda Klebe/Nieuwenboer, Niki A. Den,/Kish-Gephart, Jennifer J., (Un)Ethical Behavior in Organizations, Annual Review of Psychology, 65, 2014.

Tyler, Tom R., Trust and Law Abidingness: A Proactive Model of Social Regulation, Boston University Law Review, 81, 2001, pp. 359 ff.

Tyler, Tom R., Trust in the Law, New York, NY: Russell-Sage, 2002.

TyLER, Tom, Methodology in Legal Research, Utrecht Law Review, vol. 13, n. ${ }^{\circ}$ 3, 2017, pp. 131-133.

VON JHERING, Rudolf, Culpa in contrahendo" oder Schadensersatz bei nichtigen oder nicht zur Perfektion gelangten Verträgen, Gesammelte Aufsätze aus den Jahrbüchern für die Dogmatik des heutigen römischen und deutschen Privatrechts, Jena, 1, 1981.

WALDRon, Jeremy, The Rule of Law and the Importance of Procedure, New York Public Law and Legal Theory, 2010, p. 4.

Welsh, Nancy A., The Reputational Advantages of Demonstrating Trustworthiness: Using the Reputation Index with Law Students, Negotiation Journal, 28, 2012, pp. 118-135.

Xiao-Ying-Li-Kotovtchickhine, Pragmatisme juridique et role de la Constituition en Chine post-Mao, Revue Internationale de droit comparé, 2018, 3, 2018, pp. $446 \mathrm{ff}$ and passim.

YANG, Vincent Cheng, Corporate Crime: State-owned Enterprises in China, in: Criminal Law Forum, 6, 1995, pp. 143-165.

YATES, Memorandum from Sally Quillian, Deputy Attorney General, U.S. Department of Justice, to all U.S. Attorneys et al., Individual Accountability for Corporate Wrongdoing (Sept. 9, 2015), available at: https://www.justice.gov/archives/dag/ file/769036/download (access: 20.03.2021). 
Zhang, Mo, Pushing the Envelope: Application of Guiding Cases in Chinese Courts and Development of Case Law in China, Washington International Law Journal, 26, n. ${ }^{\circ} 2017$, pp. 268 and ff.

Zhang, Taisu, “The Pragmatic Court: Reinterpreting the Supreme People's Court of China”, Columbia Journal of Asian Law, 25, 1, 2012, 8.

ZHANG, Yingjun, Corporate Criminal Responsibility in China: Legislations and its Deficiency, Beijing Law Review, 3, 2012, pp. 103 ff.

Zhenje, Zhou, Corporate Crime in China: History and Contemporary Debates. New York: Routledge, 2016.

Zuck, R., Faires Verfahren und der Nemo tenetur-Grundsatz bei der Besuchsüberwachung zu BGH, Urteil v. 29.04.2009, Juristische Rundschau, 2010, pp. 18-27.

\section{Additional information and author's declarations (scientific integrity)}

Acknowledgement: A special thanks to Dr. Leong Cheng Hang for her unwavering support.

Conflict of interest declaration: the author confirms that there are no conflicts of interest in conducting this research and writing this article.

Declaration of authorship: all and only researchers who comply the authorship requirements of this article are listed as authors; all coauthors are fully responsible for this work in its entirety.

Declaration of originality: the author assures that the text here published has not been previously published in any other resource and that future republication will only take place with the express indication of the reference of this original publication; he also attests that there is no third party plagiarism or self-plagiarism. 


\section{Editorial process dates}

(http://www.ibraspp.com.br/revista/index.php/RBDPP/about/editorialPolicies)

- Submission: 18/04/2021

- Desk review and plagiarism check: 19/04/2021

- Correction round return 1: 20/04/2021

- Review 1: 28/05/2021

- Review 2: 08/06/2021

- Preliminary editorial decision: 04/08/2021

- Correction round return: 28/08/2021

- Final editorial decision: 21/09/2021

\section{HOW TO CITE (ABNT BRAZIL):}

SANTOS, Hugo Luz dos. Mapping out the path ahead for corporate criminal procedure law in People's Republic of China. Revista Brasileira de Direito Processual Penal, vol. 7, n. 3, p. 2015-2060, set./dez. 2021. https://doi.org/10.22197/rbdpp.v7i3.578

\section{Editorial team}

- Editor-in-chief: 1 (VGV)

- Reviewers: 2 